\title{
Using radon to understand parafluvial flows and the changing locations of groundwater inflows in the Avon River, southeast
}

\section{Australia}

\author{
Ian Cartwright ${ }^{1,2}$ and Harald Hofmann ${ }^{2,3}$ \\ ${ }^{1}$ School of Earth, Atmosphere and Environment, Monash University, Clayton, Vic. 3800, Australia \\ ${ }^{2}$ National Centre for Groundwater Research and Training, GPO Box 2100, Flinders University, Adelaide, SA 5001, Australia \\ ${ }^{3}$ School of Earth Sciences, The University of Queensland, St. Lucia, QLD 4072, Australia
}

Correspondence to: Ian Cartwright (ian.cartwright@monash.edu)

Received: 28 July 2015 - Published in Hydrol. Earth Syst. Sci. Discuss.: 10 September 2015

Revised: 4 May 2016 - Accepted: 7 August 2016 - Published: 6 September 2016

\begin{abstract}
Understanding the location and magnitude of groundwater inflows to rivers is important for the protection of riverine ecosystems and the management of connected groundwater and surface water systems. This study utilizes ${ }^{222} \mathrm{Rn}$ activities and $\mathrm{Cl}$ concentrations in the Avon River, southeast Australia, to determine the distribution of groundwater inflows and to understand the importance of parafluvial flow on the ${ }^{222} \mathrm{Rn}$ budget. The distribution of ${ }^{222} \mathrm{Rn}$ activities and $\mathrm{Cl}$ concentrations implies that the Avon River contains alternating gaining and losing reaches. The location of groundwater inflows changed as a result of major floods in 2011-2013 that caused significant movement of the floodplain sediments. The floodplain of the Avon River comprises unconsolidated coarse-grained sediments with numerous point bars and sediment banks through which significant parafluvial flow is likely. The ${ }^{222} \mathrm{Rn}$ activities in the Avon River, which are locally up to $3690 \mathrm{Bqm}^{-3}$, result from a combination of groundwater inflows and the input of water from the parafluvial zone that has high ${ }^{222} \mathrm{Rn}$ activities due to ${ }^{222} \mathrm{Rn}$ emanation from the alluvial sediments. If the high ${ }^{222} \mathrm{Rn}$ activities were ascribed solely to groundwater inflows, the calculated net groundwater inflows would exceed the measured increase in streamflow along the river by up to $490 \%$ at low streamflows. Uncertainties in the ${ }^{222} \mathrm{Rn}$ activities of groundwater, the gas transfer coefficient, and the degree of hyporheic exchange cannot explain a discrepancy of this magnitude. The proposed model of parafluvial flow envisages that water enters the alluvial sediments in reaches where the river is losing and subsequently re-enters the river in the gaining reaches with flow paths of tens to hundreds
\end{abstract}

of metres. Parafluvial flow is likely to be important in rivers with coarse-grained alluvial sediments on their floodplains and failure to quantify the input of ${ }^{222} \mathrm{Rn}$ from parafluvial flow will result in overestimating groundwater inflows to rivers.

\section{Introduction}

Quantifying groundwater inflows to streams and rivers is critical to understanding hydrogeological systems, protecting riverine ecosystems, and managing water resources (e.g. Winter, 1999; Sophocleous, 2002; Brodie et al., 2007). Groundwater inflows may form the majority of water in gaining rivers during periods of low streamflow, and riverine ecosystems are commonly sustained by groundwater inflows at those times (Kløve et al., 2011; Barron et al., 2012; Cartwright and Gilfedder, 2015). Thus, understanding the distribution and magnitude of groundwater inflows is important for managing and protecting these commonly vulnerable ecosystems. Failure to understand groundwater contributions to rivers may also result in the double allocation of water resources (i.e. surface water and groundwater allocations might represent the same water). Documenting the distribution and quantity of groundwater inflows to rivers is also required for flood forecasting, understanding the impacts of contaminants on rivers, and assessing the potential impacts of climate or land use changes on river systems.

In many catchments globally there are insufficient groundwater bores to understand the exchange between rivers and 
groundwater on anything other than a regional scale. In these cases geochemical tracers provide an alternative tool to understand groundwater-river interaction. Providing that groundwater and surface water have significantly different geochemistry, changes in the geochemistry of the river may be used to map and quantify groundwater inflows (e.g. Cook, 2013). Tracers such as major ions, stable isotopes, radioactive isotopes, and chlorofluorocarbons have been used to quantify groundwater inflows to rivers (e.g. Ellins et al., 1990; Genereux and Hemond, 1992; Négrel et al., 2001; Stellato et al., 2008; Cartwright et al., 2011, 2014; Cook, 2013; Bourke et al., 2014a, b). Geochemical tracers only quantify groundwater inflows, and while they are commonly used to determine the distribution of gaining and losing reaches, they do not quantify the magnitude of any groundwater outflows.

River water also interacts with the sediments beneath and adjacent to the streams in the hyporheic and parafluvial zones. The hyporheic zone comprises the sediments of the streambed and sides through which the river water flows due to irregularities in the streambed, and hyporheic flow generally occurs on the centimetre to tens of centimetres scale (Boulton et al., 1998). In rivers that have coarsegrained unconsolidated sediments on their floodplain, metre to hundreds of metres scale parafluvial flow may also occur (Holmes et al., 1994; Edwardson et al., 2003; Cartwright et al., 2014; Bourke et al., 2014a; Briody et al., 2016). By contrast with hyporheic exchange that occurs along the entire river, water enters the parafluvial zone in river reaches that are losing and then re-enters the river where it is gaining, augmenting the groundwater inflows. Both hyporheic exchange and parafluvial flow may impact the geochemistry of the rivers (Boulton et al., 1998; Edwardson et al., 2003; Cook et al., 2006; Cartwright et al., 2014; Bourke et al., 2014a; Briody et al., 2016) and must be taken into account when using geochemical tracers to determine groundwater inflows to rivers.

\section{$1.1 \quad{ }^{222} \mathrm{Rn}$ as a tracer of groundwater inflows}

${ }^{222} \mathrm{Rn}$, which is an intermediate isotope in the ${ }^{238} \mathrm{U}$ to ${ }^{206} \mathrm{~Pb}$ decay series, is an important tracer for quantifying groundwater inflows to rivers. ${ }^{222} \mathrm{Rn}$ has a half-life of 3.8 days and the activity of ${ }^{222} \mathrm{Rn}$ reaches secular equilibrium with its parent isotope ${ }^{226} \mathrm{Ra}$ over 3-4 weeks (Cecil and Green, 2000). Because ${ }^{226} \mathrm{Ra}$ activities in minerals in the aquifer matrix are several orders of magnitude higher than those in surface water, groundwater ${ }^{222} \mathrm{Rn}$ activities are commonly 2 or 3 orders of magnitude higher than those of surface water (Cecil and Green, 2000). This makes ${ }^{222} \mathrm{Rn}$ a viable tracer of groundwater inflows in catchments where the groundwater has similar major ion concentrations and/or stable isotope ratios to the river water. As ${ }^{222} \mathrm{Rn}$ activities in rivers decline downstream from regions of groundwater inflow due to radioactive decay and degassing to the atmosphere (Ellins et al., 1990;
Genereux and Hemond, 1992), ${ }^{222} \mathrm{Rn}$ is also useful in determining locations of groundwater inflow, even if the inflows are not quantified.

The successful application of ${ }^{222} \mathrm{Rn}$ to determine groundwater inflows, however, requires careful consideration of several processes and uncertainties. ${ }^{222} \mathrm{Rn}$ activities in groundwater may be spatially or temporally heterogeneous (Cook et al., 2006; Mullinger et al., 2007; Unland et al., 2013; Yu et al., 2013; Cartwright et al., 2011; Atkinson et al., 2015). Additionally, while it is well established that the rate of ${ }^{222} \mathrm{Rn}$ degassing increases with increasing river turbulence and decreasing river depth, it is difficult to reliably quantify the rate of degassing (Genereux and Hemond, 1992; Mullinger et al., 2007; Cook, 2013; Cartwright et al., 2014). Finally, in rivers that run through coarse alluvial sediments, water from the hyporheic or parafluvial zones may provide a source of additional ${ }^{222} \mathrm{Rn}$ to groundwater inflow (Cook et al., 2006; Cartwright et al., 2014; Bourke et al., 2014a). As has been outlined in several studies, comparison of the calculated groundwater inflows from ${ }^{222} \mathrm{Rn}$ with those made from other geochemical tracers or with streamflow measurements is a crucial test of the calculations (Cook et al., 2003, 2006; Mullinger et al., 2007, 2009; Cartwright et al., 2011, 2014; McCallum et al., 2012; Unland et al., 2013). Carrying out studies at baseflow conditions when most of the water contributing to the streams is from groundwater inflows allows for a comparison between the calculated groundwater inflows and the observed increase in streamflows, which in turn provides for a test of the parameters used in the ${ }^{222} \mathrm{Rn}$ mass balance (Cartwright et al., 2014).

\subsection{Objectives}

This paper examines groundwater-river interaction in the Avon River, southeast Australia, primarily using ${ }^{222} \mathrm{Rn}$ as a tracer. The incised nature of the Avon River and the fact that it rarely ceases to flow has led to an assumption that it receives significant groundwater inflows (Gippsland Water, 2012). There has been little attempt, however, to quantify groundwater inflows or determine their distribution, and there are insufficient groundwater monitoring bores in the catchment to understand the relationship of groundwater to the river using hydraulic data. Understanding groundwaterriver interaction is required to protect and manage the Avon River, especially in assessing the potential impacts of increased groundwater or surface water use.

The paper has two specific aims. Firstly, we use data from a 6-year period to examine whether periodic major flooding events, which alter the geometry of the Avon River floodplain, change the locations of groundwater inflows. Understanding whether the locations of groundwater inflows change following major flood events, and whether we can monitor those changes, is important to understanding groundwater-river interactions. Secondly, we assess the impacts of parafluvial exchange on the ${ }^{222} \mathrm{Rn}$ budget. The 


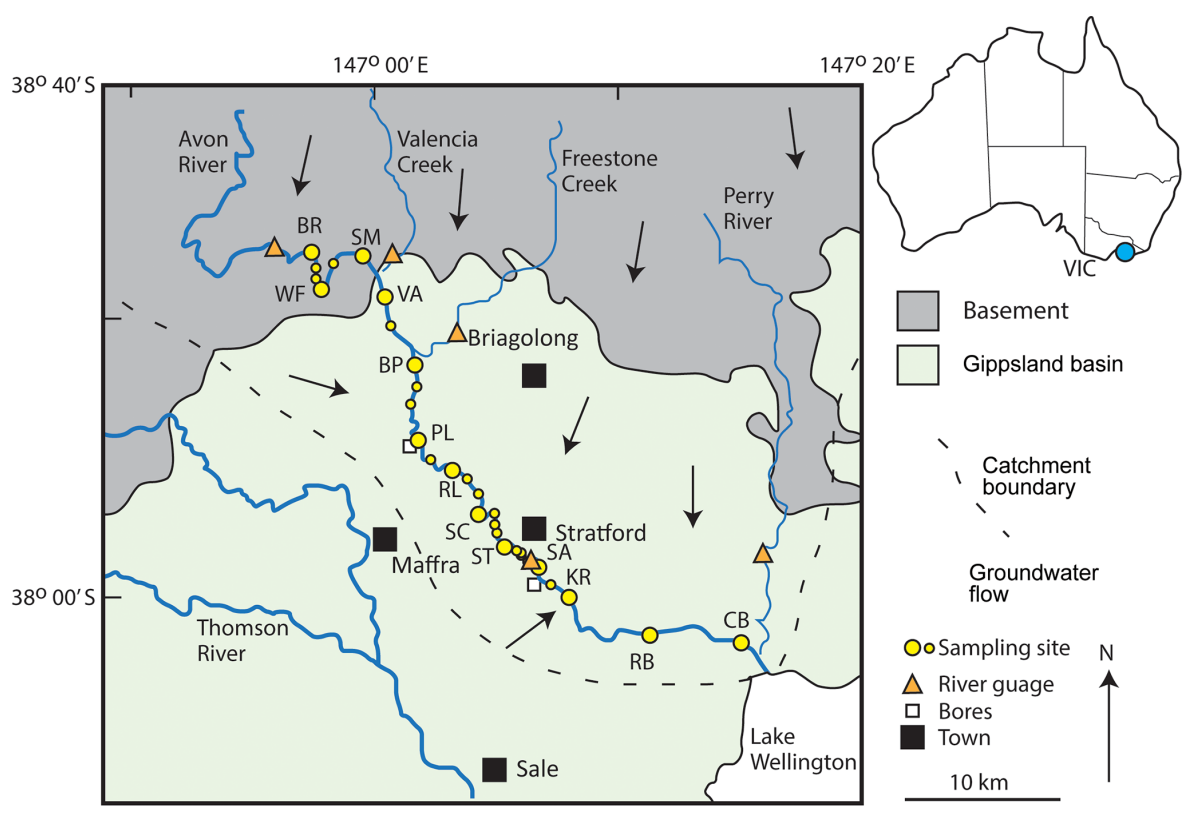

Figure 1. Summary geological and hydrogeological map of the Avon River catchment (Hofmann and Cartwright, 2015; Department of Environment and Primary Industries, 2015). Arrows show general direction of groundwater flow. Main sampling sites (in order of distance downstream are) are BR: Browns, WF: Wombat Flat, SM: Smyths Road, VA: Valencia, BP: Bushy Park, PL: Pearces Lane, RL: Ridleys Lane, SC: Schools Lane, ST: Stewarts Lane, SA: Stratford, KR: Knobs Reserve, RB: Redbank, CB: Chinns Bridge. Unnamed sampling sites are the additional sites from February 2015 (Table A1).

Avon River floodplain comprises coarse-grained unconsolidated alluvial sediments with gravel banks, point bars, and pool and riffle sections that likely host parafluvial flows. Rivers with similar coarse-grained sediments on their floodplains are common at mountain fronts and parafluvial flow is likely to be an important process in these settings. Despite parafluvial inflows being a potential important contributor of ${ }^{222} \mathrm{Rn}$ budget to rivers, few studies have explicitly considered this process in the ${ }^{222} \mathrm{Rn}$ mass balance (e.g. Bourke et al., 2014a; Cartwright et al., 2014). Thus, the results of this study will help improve the general utility of ${ }^{222} \mathrm{Rn}$ as a tracer of groundwater inflows into rivers.

\section{The Avon catchment}

The Avon River is an unregulated river in the Gippsland Basin of southeast Australia (Fig. 1) that has a total catchment area of $\sim 1830 \mathrm{~km}^{2}$ (Cochrane et al., 1991; Department of Environment and Primary Industries, 2015). It drains the southern slopes of the Victorian Alps (maximum elevation in the catchment is $1634 \mathrm{~m}$ ) and discharges into Lake Wellington, which is a coastal saline lake connected to the Southern Ocean. The highland areas represent $\sim 30 \%$ of the Avon catchment and are dominated by temperate native eucalyptus forest, whereas the majority of the plains representing $\sim 70 \%$ of the catchment have been cleared for agriculture, which includes dairying, sheep grazing, and vegetable pro- duction. The estimated population of the Avon catchment is $\sim 4000$ with Stratford being the largest town (population $\sim 2000$ ).

The highlands of the Victorian Alps comprise indurated Palaeozoic and Mesozoic igneous rocks and metasediments that only host groundwater flow in fractures or in near-surface weathered zones (Walker and Mollica, 1990; Cochrane et al., 1991). These rocks form the basement to the Tertiary and Quaternary sediments of the Gippsland Basin (Fig. 1). The shallowest regional aquifer within the Avon catchment is the Pliocene to Pleistocene Haunted Hill Formation which comprises up to $40 \mathrm{~m}$ of interbedded alluvial sands and clays that have hydraulic conductivities between $10^{-7}$ and $10^{-5} \mathrm{~m} \mathrm{~s}^{-1}$ (Brumley et al., 1982; Walker and Mollica, 1990). Quaternary sediments that consist of coarsegrained sand and gravels interbedded with finer-grained silts occur mainly within the river valleys and have hydraulic conductivities of $10^{-5}$ and $10^{-2} \mathrm{~ms}^{-1}$ (Brumley et al., 1982; Walker and Mollica, 1990).

Average rainfall within the Avon catchment ranges from $\sim 1.5 \mathrm{~m} \mathrm{yr}^{-1}$ in the highlands to $\sim 0.9 \mathrm{~m} \mathrm{yr}^{-1}$ on the plains with most precipitation occurring in the austral winter (JuneSeptember) (Bureau of Meteorology, 2015). The Avon River displays strong seasonal flows with $\sim 80 \%$ of annual streamflow occurring during winter (Department of Environment and Primary Industries, 2015). This study focusses on the reaches of the Avon River located on the plains formed by the Gippsland Basin sediments that are upstream of tidal influ- 
ence. Streamflow is measured continuously at three sites (the Channel, Stratford, and Chinns Bridge; Fig. 1). Total annual streamflow at Stratford between 1977 and 2014 was between $1.3 \times 10^{7}$ and $9.0 \times 10^{8} \mathrm{~m}^{3} \mathrm{yr}^{-1}\left(\right.$ median $\left.=3.0 \times 10^{8} \mathrm{~m}^{3} \mathrm{yr}^{-1}\right)$ and varied with total annual rainfall (Department of Environment and Primary Industries, 2015). The Avon River only ceases to flow during the summers of severe drought years (e.g. 1983) and experiences periodic floods during high rainfall periods (Fig. 2). Streamflow generally increases downstream at all times, except at very low flows when streamflow decreases between Stratford and Chinns Bridge. Valencia Creek and Freestone Creek are the main tributaries; both have streamflow measurements (Department of Environment and Primary Industries, 2015) and enter the Avon in the upper reaches of the studied section (Fig. 1).

The Avon River has incised through the Haunted Hill and Quaternary sediments to create terraces that are up to $30 \mathrm{~m}$ high with a lower floodplain that is up to $500 \mathrm{~m}$ wide. Where it crosses the sedimentary plains, the Avon River comprises a sequence of slow-flowing pools that are typically $10-30 \mathrm{~m}$ wide, up to $2 \mathrm{~m}$ deep at low flows, and up to $2 \mathrm{~km}$ long. These pools are connected by shorter (typically ten to hundreds of metres long) and narrow (typically $<5 \mathrm{~m}$ ) faster-flowing riffle sections that commonly have steep longitudinal gradients.

The floodplain of the Avon River between Browns $(0.0 \mathrm{~km})$ and Redbank $(41.3 \mathrm{~km})$ (Fig. 1) comprises numerous gravel banks and point bars of coarse-gained immature unconsolidated sediments with clasts of up to $50 \mathrm{~cm}$ in diameter. In regions where the river is incised, there are seeps of water at the base of the slope and permanent patches of water-tolerant vegetation. The alluvial sediments on the floodplain are sparsely vegetated and the geometry of the floodplain changes markedly following major flood events, such as those in 2011, 2012, and 2013 (Fig. 2). These changes include the downstream migration of pools (often by several tens of metres), scouring of the alluvial sediments, and changes to the location of the sediment banks. Downstream of Redbank, the Avon River occupies an incised channel with banks of finer-grained (clay- to sand-sized) sediments. The banks and floodplain are more vegetated and do not change markedly during the flood events.

Groundwater flows from the Victorian Alps to the coast (Hofmann and Cartwright, 2013; Fig. 1). Use of water from the Avon River and its tributaries for irrigation is up to $8 \times 10^{6} \mathrm{~m}^{3} \mathrm{yr}^{-1}(\sim 2.6 \%$ of the median annual streamflow at Stratford); however, there is a prohibition on river water use when the streamflow at Stratford is $<10^{4} \mathrm{~m}^{3}$ day $^{-1}$ (Gippsland Water, 2012).

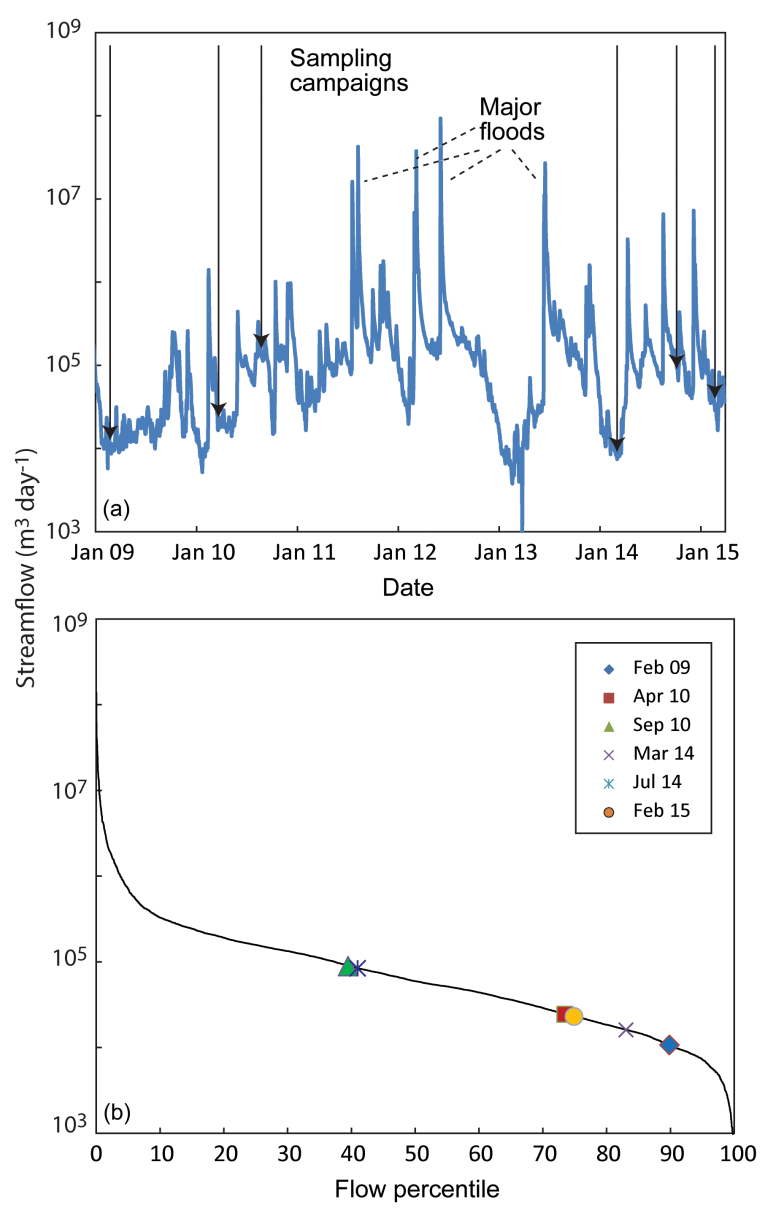

Figure 2. (a) Variation in streamflow at Stratford (Fig. 1) between January 2009 and February 2015. The major floods (highlighted) caused significant changes to the geometry of the floodplain. (b) Flow frequency curve for Stratford for streamflows between January 2000 and March 2015 and the percentiles of discharge in the sampling campaigns (data from Department of Environment and Primary Industries, 2015).

\section{Methods}

\subsection{Sampling}

Sampling took place between February 2009 and February 2015 in six campaigns at a variety of streamflows (Fig. 2a). These sampling campaigns were both before and after four major flood events that occurred between 2011 and 2013 and which caused the redistribution of the position of pools and sediment banks in the river. Each sampling campaign involved sampling the river sites (Table A1, Fig. 1) over a 2to 3-day period, with the February 2015 sampling campaign involving additional sites to the others. Distances are measured relative to the first sampling site at Browns $(0.0 \mathrm{~km})$ (Fig. 1). Streamflow is measured at three permanent gauging stations: the Channel, which is close to the first sampling site at Browns; Stratford; and Chinns Bridge (Department of 
Environment and Primary Industries, 2015; Fig. 1). Streamflow was relatively constant during the sampling periods (the variation in streamflow at Stratford over each sampling period was $<5 \%$ ). River samples were collected from 0.5 to $1 \mathrm{~m}$ below the river surface using a manual collector mounted on a pole. Groundwater was sampled from bores installed on the river bank and floodplain at Stratford and Pearces Lane (Fig. 1) that have 1 to $3 \mathrm{~m}$ long screens. Water was extracted using an impeller pump set at the screened interval and at least 3-bore volumes of water were purged before sampling. Water was also extracted from the alluvial gravels at a number of locations along the Avon River during low flow periods either from open holes or from piezometers driven 1-2 $\mathrm{m}$ below the surface of the gravels.

\subsection{Analytical techniques}

Analytical techniques were similar to those in other studies (e.g. Unland et al., 2013; Yu et al., 2013; Cartwright et al., 2014). Cations (Tables A1, A2) were analysed on samples that had been filtered through $0.45 \mu \mathrm{m}$ cellulose nitrate filters and acidified to $\mathrm{pH}<2$ using a ThermoFinnigan quadrupole ICP-MS at Monash University. Anions (Tables A1, A2) were analysed on filtered unacidified samples using a Metrohm ion chromatograph at Monash University. The precision of major ion concentrations based on replicate analyses is 2$5 \%$. A suite of anions and cations were measured; however, only $\mathrm{Cl}$ and $\mathrm{Na}$ are discussed in this study. ${ }^{222} \mathrm{Rn}$ activities in groundwater (Table A2) and surface water (Table A1) were determined using a portable radon-in-air monitor (RAD-7, Durridge Co.) following methods described by (Burnett and Dulaiova, 2006) and are expressed in becquerels per $\mathrm{m}^{3}$ of water $\left(\mathrm{Bq} \mathrm{m}^{-3}\right)$. A sample of $0.5 \mathrm{~L}$ was collected by bottom filling a glass flask and ${ }^{222} \mathrm{Rn}$ was subsequently degassed for 5 min into a closed air loop of known volume. Counting times were $2 \mathrm{~h}$ for surface water and $20 \mathrm{~min}$ for groundwater. Typical relative precision based on repeat sample measurements in this and other studies (e.g. Cartwright et al., 2011, 2014) is $<3 \%$ at $10000 \mathrm{~Bq} \mathrm{~m}^{-3}$ and $\sim 10 \%$ at $100 \mathrm{~Bq} \mathrm{~m}^{-3}$.

A total of 44 samples of riverbed sediments from sites along the Avon River were collected in March 2014 and February 2015. ${ }^{222} \mathrm{Rn}$ emanation rates $(\gamma)$ from these were determined by sealing a known dry weight of sediment in airtight containers with water and allowing ${ }^{222} \mathrm{Rn}$ to accumulate (Lamontagne and Cook, 2007). Following incubation of 4-5 weeks, by which time the rate of ${ }^{222} \mathrm{Rn}$ production and decay will have reached steady state, $20-40 \mathrm{~mL}$ of pore water was extracted and analysed for ${ }^{222} \mathrm{Rn}$ activities using the same method as above but with counting times of 6-12 h. $\gamma$ (Table 2) was calculated from ${ }^{222} \mathrm{Rn}$ produced per unit mass of sediment $E_{\mathrm{m}}$, sediment density $\rho_{\mathrm{s}}$, and porosity $\varphi$ by

$\gamma=\frac{E_{\mathrm{m}}(1-\varphi) \rho_{\mathrm{s}} \lambda}{\varphi}$

(parameters summarized in Table 1).

\subsection{Radon mass balance}

Assuming that the atmosphere contains negligible radon, the change in ${ }^{222} \mathrm{Rn}$ activities along a river is

$Q \frac{\mathrm{d} c_{\mathrm{r}}}{\mathrm{d} x}=I\left(c_{\mathrm{gw}}-c_{\mathrm{r}}\right)+w E c_{\mathrm{r}}+F_{\mathrm{h}}+F_{\mathrm{p}}-k d w c_{\mathrm{r}}-\lambda d w c_{\mathrm{r}}$

(modified from Mullinger et al., 2007; Cartwright et al., 2011; and Cook, 2013). In Eq. (2) $Q$ is streamflow; $c_{\mathrm{r}}$ and $c_{\mathrm{gw}}$ are the ${ }^{222} \mathrm{Rn}$ activities in the river and groundwater, respectively; $I$ is the groundwater flux per unit length of river; $E$ is the evaporation rate; $x$ is distance along the river; $w$ is river width; $d$ is river depth; $F_{\mathrm{h}}$ and $F_{\mathrm{p}}$ are the inputs of ${ }^{222} \mathrm{Rn}$ resulting from exchange with the hyporheic zone and inflows of parafluvial waters, respectively; $k$ is the gastransfer coefficient; and $\lambda$ is the decay constant (Table 1). A similar mass balance also applies to major ion concentrations. Since the concentration of a conservative tracer such as $\mathrm{Cl}$ is controlled only by groundwater inflows and evaporation, only the first two terms on the right-hand side of Eq. (2) are relevant. If the river is gaining throughout and solely fed by groundwater, the increase in streamflow downstream is

$\frac{\mathrm{d} Q}{\mathrm{~d} x}=I-E w$.

The ${ }^{222} \mathrm{Rn}$ activity in the hyporheic zone waters $\left(c_{\mathrm{h}}\right)$ is governed by the ${ }^{222} \mathrm{Rn}$ activity of the water flowing into the hyporheic zone $\left(c_{\text {in }}\right)$, the ${ }^{222} \mathrm{Rn}$ emanation rate $\gamma$, and the residence time $t_{\mathrm{h}}$ :

$c_{\mathrm{h}}=\left(\frac{\gamma}{\lambda}-c_{\mathrm{in}}\right)\left(1-e^{-\lambda t_{\mathrm{h}}}\right)+c_{\text {in }}$

(Hoehn et al., 1992; Hoehn and Cirpka, 2006) (Fig. 3a). An identical expression relates the ${ }^{222} \mathrm{Rn}$ activity in the parafluvial zone waters $\left(c_{\mathrm{p}}\right)$ to the residence time of that water in the parafluvial zone $\left(t_{\mathrm{p}}\right), c_{\mathrm{h}}$ increases with $t_{\mathrm{h}}$ until secular equilibrium is approached at which point $c_{\mathrm{h}}=\gamma / \lambda$. In a losing or neutral (i.e. neither gaining nor losing) river $c_{\text {in }}=c_{\mathrm{r}}$. In a gaining river, water derived from the river will mix in the alluvial sediments with upwelling regional groundwater that has high ${ }^{222} \mathrm{Rn}$ activities. Cartwright et al. (2014) discussed using the concentration of a conservative ion such as $\mathrm{Cl}$ to estimate the degree of mixing within the alluvial sediments to estimate $c_{\text {in }}$. Assuming that all the water entering the hyporheic zone subsequently re-enters the river, the ${ }^{222} \mathrm{Rn}$ flux from the hyporheic zone $\left(F_{\mathrm{h}}\right)$ is

$F_{\mathrm{h}}=\frac{\gamma A_{\mathrm{h}} \varphi}{1+\lambda t_{\mathrm{h}}}-\frac{\lambda A_{\mathrm{h}} \varphi}{1+\lambda t_{\mathrm{h}}} c_{\mathrm{in}}$,

where $A_{\mathrm{h}}$ is the cross-sectional area of the hyporheic zone (Lamontagne and Cook, 2007). Equation (5) treats the hyporheic zone as a homogeneous region adjacent to the river in which river water resides for a certain period of time and then re-enters the river. While recognizing that this is an oversimplification, it provides a means of calculating the changes 
Table 1. Summary of parameters used in ${ }^{222} \mathrm{Rn}$ mass balance.

\begin{tabular}{|c|c|c|c|}
\hline Symbol & Parameter & Units & Comments \\
\hline$Q$ & Streamflow & $\mathrm{m}^{3}$ day $^{-1}$ & \\
\hline$E$ & Evaporation & $\mathrm{mday}^{-1}$ & \\
\hline$x$ & Distance downstream & $\mathrm{m}$ & \\
\hline$w$ & Stream width & $\mathrm{m}$ & \\
\hline$d$ & Stream depth & $\mathrm{m}$ & \\
\hline$v$ & Stream velocity & mday $^{-1}$ & \\
\hline$c_{\mathrm{gw}}, c_{\mathrm{r}}, c_{\mathrm{h}}, c_{\mathrm{p}}$ & ${ }^{222} \mathrm{Rn}$ activities in groundwater, river, hyporheic zone, parafluvial zone & $\mathrm{Bqm}^{-3}$ & \\
\hline$c_{\text {in }}$ & ${ }^{222} \mathrm{Rn}$ activity of water entering the hyporheic or parafluvial zone & $\mathrm{Bqm}^{-3}$ & \\
\hline$k$ & Gas-transfer coefficient & day $^{-1}$ & \\
\hline$\lambda$ & Decay constant & $0.181 \mathrm{day}^{-1}$ & \\
\hline$I$ & Groundwater inflows & $\mathrm{m}^{3} \mathrm{~m}^{-1} \mathrm{day}^{-1}$ & Eq. (2) \\
\hline$F_{\mathrm{h}}$ & ${ }^{222} \mathrm{Rn}$ flux from hyporheic zone & $\mathrm{Bqm}^{-1}$ day $^{-1}$ & Eq. (5) \\
\hline$F_{\mathrm{p}}$ & ${ }^{222} \mathrm{Rn}$ flux from parafluvial zone & $\mathrm{Bqm}^{-1} \mathrm{day}^{-1}$ & Eq. (6) \\
\hline$\gamma$ & ${ }^{222} \mathrm{Rn}$ emanation rate & $\mathrm{Bqm}^{-3} \mathrm{day}^{-1}$ & Eq. (1) \\
\hline$E_{\mathrm{m}}$ & ${ }^{222} \mathrm{Rn}$ produced from sediments & $\mathrm{Bq} \mathrm{kg}^{-1}$ & \\
\hline$\rho_{\mathrm{S}}$ & Sediment density & $\mathrm{kg} \mathrm{m}^{-3}$ & \\
\hline$I_{\mathrm{p}}$ & Inflows from parafluvial zone & $\mathrm{m}^{3} \mathrm{~m}^{-1} \mathrm{day}^{-1}$ & \\
\hline$t_{\mathrm{h}}, t_{\mathrm{p}}$ & Residence time in hyporheic or parafluvial zone & day & \\
\hline$\varphi$ & Porosity & & \\
\hline$V_{\mathrm{p}}$ & Volume of sediments that parafluvial inflows interact with & $\mathrm{m}^{3} \mathrm{~m}^{-1}$ & \\
\hline$A_{\mathrm{h}}, A_{\mathrm{p}}$ & Cross-sectional area of the hyporheic or parafluvial zone & $\mathrm{m}^{2}$ & $A_{\mathrm{p}}=V_{\mathrm{p}}$ \\
\hline
\end{tabular}

in ${ }^{222} \mathrm{Rn}$ in the hyporheic zone from estimates of emanation rates and the dimensions of the hyporheic zone.

Equation (5) may also be used to calculate $c_{\mathrm{p}}$ from $t_{\mathrm{p}}$ and $\gamma$ (e.g. Cartwright et al., 2014). However, where parafluvial flow involves long flow paths through alluvial sediments, an alternative conceptualization is to consider the flux of ${ }^{222} \mathrm{Rn}$ into the river at the end of discrete flow paths through the parafluvial zone (Hoehn and Von Gunten, 1989; Hoehn and Cirpka, 2006; Bourke et al., 2014a). In that case, $F_{\mathrm{p}}$ is given by a similar expression to that which accounts for the input of ${ }^{222} \mathrm{Rn}$ due to groundwater inflows:

$F_{\mathrm{p}}=I_{\mathrm{p}}\left(c_{\mathrm{p}}-c_{\mathrm{r}}\right)$,

where $I_{\mathrm{p}}$ is the flux of water from the parafluvial zone per unit length of the river. The minimum $I_{\mathrm{p}}$ required to produce a given $F_{\mathrm{p}}$ is achieved when $c_{\mathrm{p}}$ approaches steady state (Fig. 3b), which requires $t_{\mathrm{h}}$ to be at least several days $\left(c_{\mathrm{p}}\right.$ is $\sim 95 \%$ of the steady state activity after 16 days; Fig. 3a). If $t_{\mathrm{h}}$ is less than the time required to achieve steady state, $c_{\mathrm{p}}$ is lower, and a higher $I_{\mathrm{p}}$ is required to achieve the same $F_{\mathrm{p}}$. The volume of sediments with which the water has interacted during flow through the parafluvial zone $\left(V_{\mathrm{p}}\right.$ in $\mathrm{m}^{3}$ per meter of flow path length of river) is governed by $I_{\mathrm{p}}, t_{\mathrm{p}}$, and $\varphi$. If the flow paths through the parafluvial zone are regular, $V_{\mathrm{p}}$ will be the cross-sectional area of the parafluvial zone through which the water from the river flows $\left(A_{\mathrm{p}}\right)$ :

$V_{\mathrm{p}}=A_{\mathrm{p}}=\frac{t_{\mathrm{p}} I_{\mathrm{p}}}{\varphi}$
(Bourke et al., 2014a). For the same input parameters, Eqs. (5) and (6) yield closely similar estimates of $F_{\mathrm{p}}$ (Bourke et al., 2014a) and the least well-known parameters in both cases are $A_{\mathrm{p}}$ and $t_{\mathrm{p}}$.

There are several approaches that may be used to estimate the rate of ${ }^{222} \mathrm{Rn}$ degassing from rivers. Firstly, as degassing involves diffusion of ${ }^{222} \mathrm{Rn}$ through the boundary layer at the river surface, the stagnant film model yields a gas transfer velocity as $D / z$ (which is closely related to $k$ ), where $z$ is the thickness of the boundary layer at the water surface (Ellins et al., 1990; Stellato et al., 2008). $z$ and by extension $D / z$ can be calculated from differences in river ${ }^{222} \mathrm{Rn}$ concentrations in losing reaches. The gas transfer coefficient $k$ may be estimated in a similar way from the change in ${ }^{222} \mathrm{Rn}$ activities in losing reaches (e.g. Cartwright et al., 2011; Cook 2013) or even in gaining reaches if groundwater inflows have been estimated using other tracers, numerical models, streamflow measurements, and/or streambed temperature profiles (Cook et al., 2003; Cartwright et al., 2014; Cartwright and Gilfedder, 2015). Determining $k$ or $z$ by comparing calculated and measured ${ }^{222} \mathrm{Rn}$ activities requires that the ${ }^{222} \mathrm{Rn}$ contributed from the hyporheic or parafluvial zones is quantified, and that there are no inflows of water from tributaries that may increase or decrease ${ }^{222} \mathrm{Rn}$ activities. Since $k$ values are typically calculated from these methods for a few specific wellunderstood river reaches, it is possible that they are not valid for all river reaches.

It is also possible to measure $k$ directly by using introduced gas tracers such as $\mathrm{SF}_{6}$ (Cook et al., 2003, 2006; McCallum 
Table 2. ${ }^{222} \mathrm{Rn}$ emanation rates from floodplain sediments.

\begin{tabular}{|c|c|c|c|}
\hline Site*/Sample & $\begin{array}{c}E_{\mathrm{m}} \\
\left(\mathrm{Bqkg}^{-1}\right)\end{array}$ & $\left(\mathrm{Bqm}^{-3}\right.$ day $\left.^{-1}\right)$ & $\begin{array}{c}\gamma / \lambda \\
\left(\mathrm{Bqm}^{-3}\right)\end{array}$ \\
\hline Chinns Bridge 1 & 2.01 & 1473 & 8138 \\
\hline Chinns Bridge 2 & 4.02 & 2949 & 16293 \\
\hline Wombat Flat 1 & 4.04 & 2964 & 16376 \\
\hline Wombat Flat 2 & 4.52 & 3311 & 18295 \\
\hline Wombat Flat 3 & 4.19 & 3075 & 16988 \\
\hline Wombat Flat 4 & 6.13 & 4492 & 24819 \\
\hline Valencia 1 & 3.95 & 2899 & 16016 \\
\hline Valencia 2 & 1.86 & 1362 & 7525 \\
\hline Pearces Lane 1 & 0.62 & 454 & 2506 \\
\hline Pearces Lane 2 & 3.25 & 2383 & 13167 \\
\hline Pearces Lane 3 & 1.41 & 1034 & 5722 \\
\hline Pearces Lane 4 & 2.63 & 1925 & 10636 \\
\hline Pearces Lane 5 & 6.76 & 4952 & 27360 \\
\hline Pearces Lane 6 & 5.60 & 4107 & 22689 \\
\hline Pearces Lane 7 & 4.12 & 3018 & 16674 \\
\hline Pearces Lane 8 & 1.54 & 1127 & 6225 \\
\hline Stewarts Lane 1 & 3.41 & 2497 & 13797 \\
\hline Stewarts Lane 2 & 5.78 & 4239 & 23418 \\
\hline Stewarts Lane 3 & 3.08 & 2258 & 12475 \\
\hline Stewarts Lane 4 & 2.88 & 2110 & 11656 \\
\hline Stewarts Lane 5 & 4.63 & 3391 & 18732 \\
\hline Stewarts Lane 6 & 3.64 & 2669 & 14745 \\
\hline Stewarts Lane 7 & 4.52 & 3311 & 18294 \\
\hline Stewarts Lane 8 & 4.58 & 3354 & 18530 \\
\hline Stewarts Lane 9 & 1.96 & 1434 & 7925 \\
\hline Stewarts Lane 10 & 5.09 & 3733 & 20622 \\
\hline Stewarts Lane 11 & 4.25 & 3119 & 17230 \\
\hline Stewarts Lane 12 & 3.68 & 2699 & 14910 \\
\hline Stewarts Lane 13 & 1.77 & 1294 & 7150 \\
\hline Stewarts Lane 14 & 2.89 & 2122 & 11723 \\
\hline Stratford 1 & 2.13 & 1563 & 8634 \\
\hline Stratford 2 & 0.66 & 482 & 2663 \\
\hline Stratford 3 & 3.01 & 2206 & 12190 \\
\hline Stratford 4 & 3.77 & 2762 & 15259 \\
\hline Stratford 5 & 0.39 & 288 & 1591 \\
\hline Stratford 6 & 1.24 & 911 & 5032 \\
\hline Stratford 7 & 2.00 & 1469 & 8117 \\
\hline Stratford 8 & 2.71 & 1985 & 10965 \\
\hline Stratford 9 & 0.91 & 668 & 3692 \\
\hline Stratford 10 & 1.01 & 738 & 4077 \\
\hline Stratford 11 & 4.55 & 3334 & 18419 \\
\hline Stratford 12 & 3.13 & 2293 & 12667 \\
\hline Stratford 13 & 0.81 & 491 & 3282 \\
\hline Mean & & 2308 & 12751 \\
\hline$\sigma$ & & 1197 & 6615 \\
\hline
\end{tabular}

* sites in Fig. 2
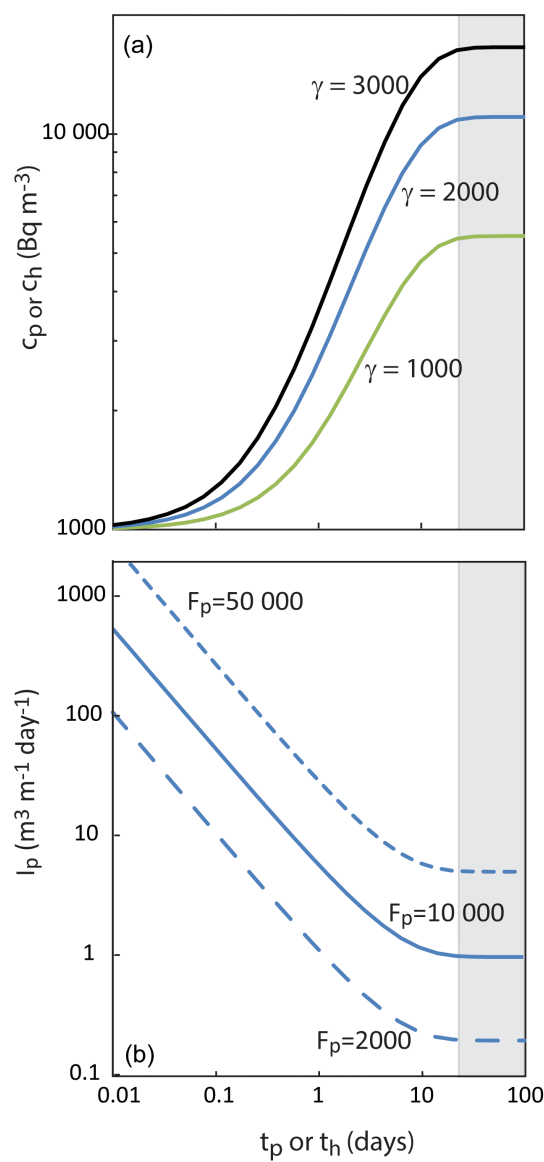

Figure 3. (a) Variation in the ${ }^{222} \mathrm{Rn}$ activity in the parafluvial or hyporheic zone $\left(c_{\mathrm{p}}\right.$ or $\left.c_{\mathrm{h}}\right)$ with residence time $\left(t_{\mathrm{p}}\right.$ or $\left.t_{\mathrm{h}}\right)$ and ${ }^{222} \mathrm{Rn}$ emanation rate $(\gamma)$ (Eq. 3). (b) Variation in the water flux from the parafluvial zone $\left(I_{\mathrm{p}}\right)$ with the flux of ${ }^{222} \mathrm{Rn}$ from the parafluvial zone $\left(F_{\mathrm{p}}\right)$ and $t_{\mathrm{p}}$ (Eq. 5). In both cases $c_{\mathrm{r}}=c_{\text {in }}=1000 \mathrm{Bqm}^{-3}$.

et al., 2012; Bourke et al., 2014a), which has the advantage of estimating $k$ for the river being studied. However, such measurements are generally made along small reaches of a river that may not be representative of the river as a whole. Additionally, if the experiments were made at specific flow conditions, the gas transfer coefficients may or may not be applicable to sampling campaigns made at different flow conditions.

There are several empirical relationships that estimate $k$ from river velocities $(v)$ and depths. The commonly used O'Connor and Dobbins (1958) and Negulescu and Rojanski (1969) gas transfer equations as modified for ${ }^{222} \mathrm{Rn}$ are

$$
\begin{aligned}
& k=9.301 \times 10^{-3}\left(\frac{v^{0.5}}{d^{1.5}}\right), \\
& k=4.87 \times 10^{-4}\left(\frac{v}{d}\right)^{0.85}
\end{aligned}
$$

(Mullinger et al., 2007). As discussed by Genereux and Hemond (1992), however, there are numerous formulations that can yield very different estimates of $k$ for the same flow 


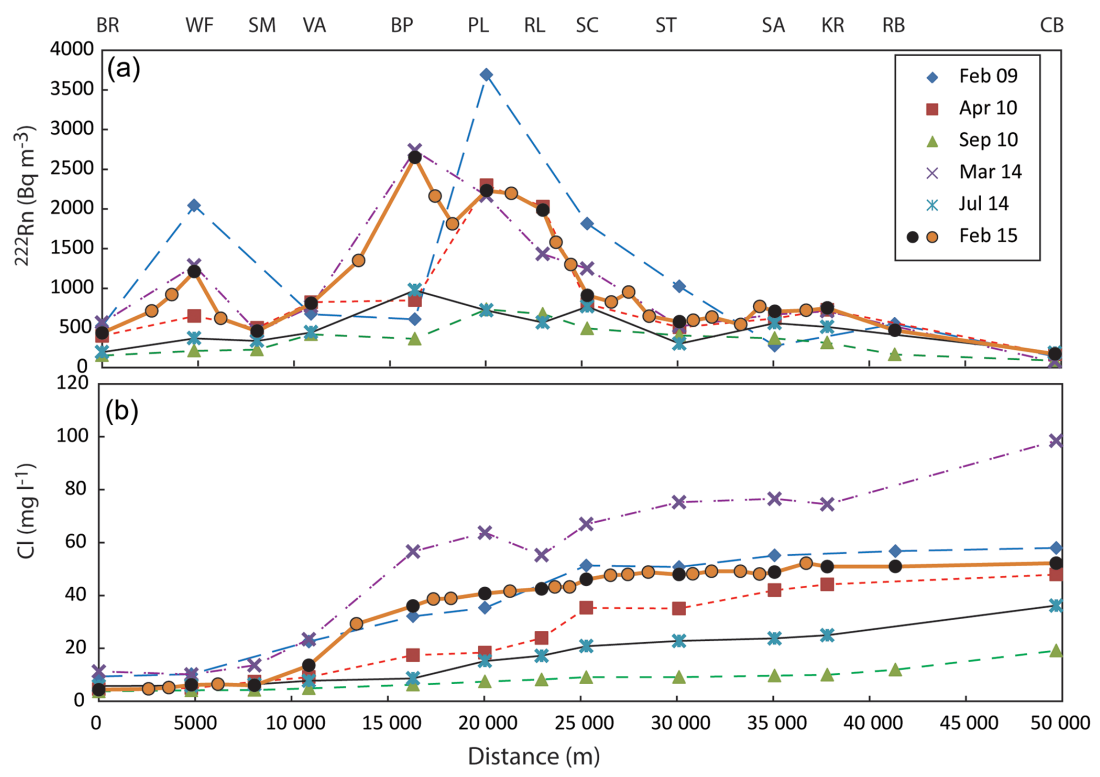

Figure 4. Downstream variations in ${ }^{222} \mathrm{Rn}$ activities (a) and $\mathrm{Cl}$ concentrations (b) for the six sampling campaigns (data from Table A1, abbreviations are as for Fig. 2). Closed symbols for February 2015 are from the main sites, open symbols are from the additional sites specific to that sampling campaign (Table A1). Site abbreviations are as for Fig. 1.

conditions and some independent assessment of $k$ (for example, by matching the predicted and observed decline in ${ }^{222} \mathrm{Rn}$ activities in losing reaches) is needed.

\section{Results}

\subsection{Streamflow}

Between January 2000 and February 2015 streamflow at Stratford varied between 500 and $1.38 \times 10^{8} \mathrm{~m}^{3} \mathrm{day}^{-1}$ (Department of Environment and Primary Industries, 2015). Despite this period including years with well below average rainfall (for example, in 2006 when rainfall was $\sim 50 \%$ of the long-term average; Bureau of Meteorology, 2015), there were no periods of zero streamflow. Mean daily streamflows at Stratford during the sampling rounds ranged from 10670 to $88800 \mathrm{~m}^{3}$ day $^{-1}$ (Table A1, Fig. 2a) which represent streamflow percentiles of 39.5-89.9 (Fig. 2b). In February 2015 , which is the sampling round discussed in most detail below, the mean daily streamflow was $12510 \mathrm{~m}^{3} \mathrm{day}^{-1}$ at the Channel, $23090 \mathrm{~m}^{3} \mathrm{day}^{-1}$ at Stratford, and $25780 \mathrm{~m}^{3} \mathrm{day}^{-1}$ at Chinns Bridge. Inflows from Valencia Creek and Freestone Creek in February 2015 were 1410 and $600 \mathrm{~m}^{3} \mathrm{day}^{-1}$, respectively (Department of Environment and Primary Industries, 2015).

\subsection{River geochemistry}

Figure $4 \mathrm{a}$ shows the ${ }^{222} \mathrm{Rn}$ activities of the Avon River for the six sampling campaigns. There are several distinct zones of elevated ${ }^{222} \mathrm{Rn}$ activities, notably at Wombat Flat $(4.8 \mathrm{~km})$ where ${ }^{222} \mathrm{Rn}$ activities are up to $2040 \mathrm{~Bq} \mathrm{~m}^{-3}$ and between Bushy Park and Schools Lane (16.3-25.3 km) where ${ }^{222} \mathrm{Rn}$ activities are up to $3690 \mathrm{~Bq} \mathrm{~m}^{-3}$. Zones of lower ${ }^{222} \mathrm{Rn}$ activities in the upper reaches occur at Smyths Road $(8.1 \mathrm{~km})$ and in the reaches between Stewarts Lane and Stratford (30.1$35.1 \mathrm{~km}$ ). The downstream river reaches between Knobs Reserve and Chinns Bridge (37.8-49.7 km) also have relatively low ${ }^{222} \mathrm{Rn}$ activities that generally decline downstream. The position of the highest ${ }^{222} \mathrm{Rn}$ activities changed in the periods prior to and after the 2011-2013 floods. In March 2014 and February 2015, the highest ${ }^{22} \mathrm{Rn}$ activities were at Bushy Park $(16.3 \mathrm{~km})$, whereas this site had relatively low ${ }^{222} \mathrm{Rn}$ activities in February 2009 and April 2010 when the highest ${ }^{222} \mathrm{Rn}$ activities were at Pearces Lane $(20.0 \mathrm{~km})$. The distribution of ${ }^{222} \mathrm{Rn}$ activities in the detailed sampling campaign in February 2015 is similar to that at other periods of low to moderate streamflow (e.g. March 2014). The lowest overall ${ }^{222} \mathrm{Rn}$ activities were recorded during the periods of highest flow (September 2010 and July 2014).

$\mathrm{EC}$ values and $\mathrm{Cl}$ concentrations generally increase downstream from 54 to $131 \mu \mathrm{Scm}^{-1}$ and from 4 to $10 \mathrm{mg} \mathrm{L}^{-1}$ at Browns $(0.0 \mathrm{~km})$ to as high as $934 \mu \mathrm{S} \mathrm{cm}^{-1}$ and $98 \mathrm{mg} \mathrm{L}^{-1}$ at Chinns Bridge $(49.7 \mathrm{~km})$ (Table A1, Fig. 4b). Cl concentrations at low streamflows in March 2014 were generally higher (up to $98 \mathrm{mg} \mathrm{L}^{-1}$ ) than in the other sampling campaigns, while $\mathrm{Cl}$ concentrations were $<20 \mathrm{mg} \mathrm{L}^{-1}$ during the highest streamflows in September 2010. A marked increase in $\mathrm{EC}$ values and $\mathrm{Cl}$ concentrations occurs downstream of Smyths Road $(8.1 \mathrm{~km})$ in the reaches where ${ }^{222} \mathrm{Rn}$ activities are highest at low streamflows. The concentrations of other 
major ions (e.g. Na) increase downstream in a similar manner (Table A1).

\subsection{Groundwater geochemistry}

Groundwater from the near-river bores at Pearces Lane and Stratford has ${ }^{222} \mathrm{Rn}$ activities that vary from 480 to $28980 \mathrm{~Bq} \mathrm{~m}^{-3}$ (Table A2). There is some variation in ${ }^{222} \mathrm{Rn}$ activities in individual bores between the sampling rounds with relative standard deviations between 6 and $34 \%$. The mean value of all groundwater ${ }^{222} \mathrm{Rn}$ activities $(n=26)$ is $12890 \mathrm{Bqm}^{-3}$. Bore 5 at Pearces Lane is immediately adjacent to the Avon River and possibly samples water from the parafluvial zone rather than groundwater. Excluding data from that bore, the mean value of ${ }^{222} \mathrm{Rn}$ activities is $13830 \mathrm{Bqm}^{-3}(n=24)$ with a standard error of $1273 \mathrm{~Bq} \mathrm{~m}^{-3}$ and a $95 \%$ confidence interval (calculated using the descriptive statistics tool in Excel 2010 which assumes that the data follow a $t$ distribution) of $2634 \mathrm{~Bq} \mathrm{~m}^{-3}$. EC values of groundwater from the bores at Pearces Lane and Stratford are between 100 and $680 \mu \mathrm{Scm}^{-1}$ and $\mathrm{Cl}$ concentrations range from 46 to $147 \mathrm{mgL}^{-1}$ with a mean value of $79 \pm 34 \mathrm{mg} \mathrm{L}^{-1}(n=16)$ (Table A2). If Bore 5 at Pearces Lane is again excluded, the mean $\mathrm{Cl}$ concentration is $87 \pm 28 \mathrm{mg} \mathrm{L}^{-1}(n=14)$ with a standard error of $8 \mathrm{mg} \mathrm{L}^{-1}$ and a $95 \%$ confidence interval of $16 \mathrm{mg} \mathrm{L}^{-1}$. These $\mathrm{Cl}$ concentrations are typical of groundwater elsewhere in the Avon valley and neighbouring catchments (Department of Environment and Primary Industries, 2015).

\subsection{Geochemistry of water from the alluvial gravels}

EC values of water within the gravels further than 1-2 m from the edge of the river are between 120 and $550 \mu \mathrm{S} \mathrm{cm}^{-1}$ $(n=52)$ (Fig. 5b). These EC values are higher than those of the adjacent river water but similar to those of the groundwater. Only water extracted from within 1 to $2 \mathrm{~m}$ from the river had EC values similar to the river and in some cases the EC of water from the gravels within a few centimetres of the river edge was higher than the adjacent river. ${ }^{222} \mathrm{Rn}$ activities of these samples were between 7000 and $28000 \mathrm{~Bq} \mathrm{~m}^{-3}$ $(n=21)$ (Fig. 5a), which are also significantly higher than the ${ }^{222} \mathrm{Rn}$ activities in the adjacent river. As discussed below, these data are interpreted as indicating that the gravels contain a mixture of groundwater and parafluvial water.

\section{5 $\quad{ }^{222} \mathrm{Rn}$ emanation rates}

${ }^{222} \mathrm{Rn}$ emanation rates were determined via Eq. (1). The matrix density was assigned as $2700 \mathrm{~kg} \mathrm{~m}^{-3}$, which is appropriate for sediments rich in quartz $\left(\rho=2650 \mathrm{~kg} \mathrm{~m}^{-3}\right)$, and a porosity of 0.4 was used, which is appropriate for unconsolidated poorly sorted riverine sediments (Freeze and Cherry, 1979). $\gamma$ values range from 288 to $4950 \mathrm{~Bq} \mathrm{~m}^{-3}$ with a mean value of $2308 \pm 1197 \mathrm{Bqm}^{-3}(n=44)$ and a standard error of $183 \mathrm{Bqm}^{-3}$. The mean emanation rates for

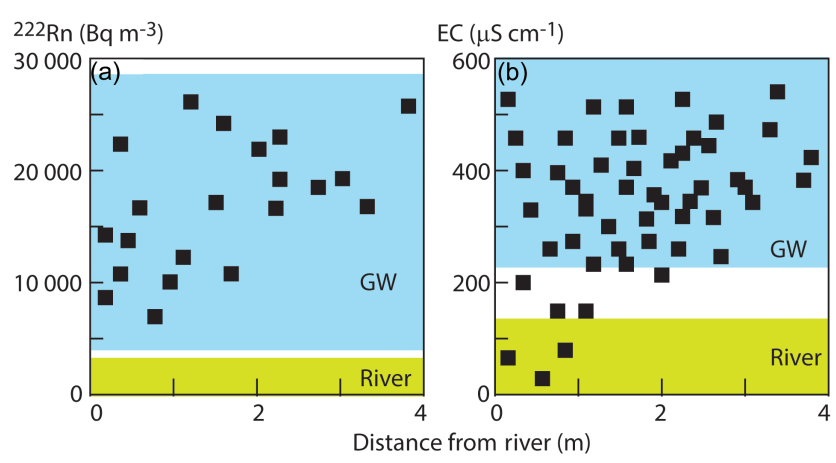

Figure 5. Variations in ${ }^{222} \mathrm{Rn}$ activities (a) and EC values (b) of water extracted from river bank gravels. Shaded boxes show range of values in the groundwater (excluding Bore 5 at Pieces Lane) and the Avon River (data from Tables A1 and A2).

sediments from the different sites vary between 1484 and $3461 \mathrm{~Bq} \mathrm{~m}^{-3}$; however, there is no systematic variation with position in the catchment. The relative variability in $\gamma$ between the sediments is similar to that reported elsewhere (e.g. Bourke et al., 2014a; Cartwright et al., 2014). ${ }^{222} \mathrm{Rn}$ activities of water in equilibrium with the sediments are given by $\gamma / \lambda$ (Cecil and Green, 2000), and the mean $\gamma / \lambda$ value is $12751 \pm 6615 \mathrm{Bqm}^{-3}$ with a standard error of $1009 \mathrm{Bqm}^{-3}$. These $\gamma / \lambda$ values are not significantly different $(p \sim 0.5)$ to the measured ${ }^{222} \mathrm{Rn}$ activities of the groundwater.

\section{Discussion}

The following observations imply that overall the Avon is a gaining river: (1) even during periods of prolonged low rainfall the river continues to flow and streamflow commonly increases between the Channel and Chinns Bridge gauges; (2) ${ }^{222} \mathrm{Rn}$ activities are higher than those that could be maintained by hyporheic exchange alone (Cartwright et al., 2011; Cook, 2013); (3) Cl concentrations increase downstream; and (4) there are seeps of water (presumed to be groundwater) at the base of steep slopes at the edge of the floodplain. In the following section, the ${ }^{222} \mathrm{Rn}$ activities and $\mathrm{Cl}$ concentrations are used to assess the location and magnitude of groundwater inflows.

\subsection{Distribution of groundwater inflows}

The February 2009, April 2010, March 2014, and February 2015 sampling campaigns represent lower streamflows. Because the majority of water in the Avon River at these times is likely to be provided by groundwater, the ${ }^{222} \mathrm{Rn}$ activities from these sampling campaigns are most useful in understanding the distribution of groundwater inflows. The region between Smyths Road and Ridleys Lane (8.1-23.0 km) where ${ }^{222} \mathrm{Rn}$ activities increase and remain high (Fig. 4a), especially at lower streamflows, and where there is a marked 
increase in $\mathrm{Cl}$ concentrations (Fig. 4b), is interpreted as receiving major groundwater inflows. This section of the Avon River is incised up to $4 \mathrm{~m}$ below the floodplain which likely produces steep hydraulic head gradients that result in groundwater discharge on the floodplain and into the river. There are also groundwater seeps and patches of perennial watertolerant vegetation at the edge of the floodplain in this area. The reaches between Browns and Wombat Flat $(0.0-4.8 \mathrm{~km})$ and Stewarts Lane and Stratford $(30.1-35.1 \mathrm{~km})$ are also characterized by high ${ }^{222} \mathrm{Rn}$ activities and are again interpreted as receiving groundwater inflows.

The reaches between Wombat Flat and Smyths Road (4.8$8.1 \mathrm{~km})$, Ridleys Lane and Stewarts Lane (23.0-30.1 km), and Knobs Reserve and Chinns Bridge (37.8-49.7 km) where there is a gradual decline in ${ }^{222} \mathrm{Rn}$ activities and little change in $\mathrm{Cl}$ concentrations (Fig. 4) are interpreted as either being losing or receiving minor groundwater inflows. The landscape is flatter and the river is less incised in these areas which results in lower hydraulic gradients and consequently less groundwater inflows to the river.

The difference in the location of the highest ${ }^{222} \mathrm{Rn}$ activities between the sampling campaigns that were conducted before and after the major floods (i.e. pre-2011 vs. post-2013) indicates that the locations of groundwater inflows changed. The major floods changed the location of pools and sediment banks on the Avon River and caused scouring, which would change the relationship of the river to the groundwater.

\subsection{Quantifying groundwater inflows}

This section concentrates on modelling the ${ }^{222} \mathrm{Rn}$ activities for the detailed February 2015 sampling campaign (Fig. 4a). It was considered that groundwater inflows, hyporheic exchange, and parafluvial flow all contributed ${ }^{222} \mathrm{Rn}$ to the river. The groundwater ${ }^{222} \mathrm{Rn}$ activity was assumed to be $13000 \mathrm{~Bq} \mathrm{~m}^{-3}$, which is consistent both with the measured ${ }^{222} \mathrm{Rn}$ activities of groundwater (Table A2) and the calculated ${ }^{222} \mathrm{Rn}$ activities of water in equilibrium with the alluvial sediments.

The flux of ${ }^{222} \mathrm{Rn}$ from the hyporheic zone was estimated from Eq. (5) using the mean $\gamma$ value of $2300 \mathrm{~Bq} \mathrm{~m}^{-3} \mathrm{day}^{-1}$ (Table 2), a porosity of 0.4 (which is appropriate for coarsegrained unconsolidated sediments), and a value for $c_{\text {in }}$ that is the ${ }^{222} \mathrm{Rn}$ activity of the river in that reach. The residence time of water within the hyporheic zone is likely to be short (Boulton et al., 1998; Tonina and Buffington, 2011; Zarnetske et al., 2011; Cartwright et al., 2014), and $t_{\mathrm{h}}=0.1$ days is assumed here; for $t_{\mathrm{h}}<1$ day, $F_{\mathrm{h}}$ is relatively insensitive to the actual residence times in the hyporheic zone (Lamontagne and Cook, 2007; Cartwright et al., 2014). The width of the hyporheic zone has been assigned as the river width. The thickness of the hyporheic zone is less well known; however, by analogy with rivers elsewhere, it is likely to be a few centimetres thick (Boulton et al., 1998; Hester and Doyle, 2008;
Tonina and Buffington, 2011) and a value of $10 \mathrm{~cm}$ is initially adopted.

Parafluvial flow is conceived to occur on the tens of metres to kilometre scale and to represent water that is lost from the river into the floodplain sediments that subsequently reenters the river downstream. The $\mathrm{Cl}$ and ${ }^{222} \mathrm{Rn}$ data from the water contained within the gravels (Fig. 5) are interpreted as reflecting mixing of groundwater and parafluvial flows in the coarse-grained gravel. The generation of paraluvial flow requires that the river is locally losing. As discussed above, on the kilometre scale the Avon River may contain losing reaches. Additionally, the reaches that are interpreted as being overall gaining may contain smaller sections that are losing. In particular, the riffle sections commonly have steep longitudinal gradients and may transition from losing at the upstream end to gaining at the downstream end. Parafluvial flow is probably hosted mainly within the coarser-grained alluvial sediments (although conceivably it could also include water that flows through the upper levels of the aquifers underlying the alluvial sediments). By contrast with hyporheic exchange which occurs along all reaches (whether gaining or losing), inflows from the parafluvial zone require upward head gradients and only occur where the river is gaining. The parafluvial inflows will increase the ${ }^{222} \mathrm{Rn}$ activities in the river in a similar manner to inflowing groundwater. However, because it represents water that originated from the river, the inflows from the parafluvial zone do not increase the overall streamflow. If the parafluvial zone water is in secular equilibrium with the sediments, $c_{\mathrm{p}} \sim 12700 \mathrm{~Bq} \mathrm{~m}^{-3}$ (Table 2).

Average evaporation rates in southeast Australia in February to April are $3 \times 10^{-3}$ to $5 \times 10^{-3} \mathrm{mday}^{-1}$ (Bureau of Meteorology, 2015) and a value of $4 \times 10^{-3} \mathrm{mday}^{-1}$ was adopted. Average river width and depth is 10 and $0.5 \mathrm{~m}$, respectively, upstream of Wombat Flat $(0.0-4.8 \mathrm{~km})$ and 20 and $1 \mathrm{~m}$, respectively, for the rest of the river

The gas transfer coefficient was estimated from the decline in ${ }^{222} \mathrm{Rn}$ activities between Ridleys Lane and Schools Lane (23.0-25.3 km) (Fig. 4a). This approach estimates the net $k d w c_{\mathrm{r}}$ term and $k$ was estimated as 0.3 day $^{-1}$ using the measured widths, depths, and ${ }^{222} \mathrm{Rn}$ concentrations. This requires that this is a losing stretch of the river, so that there are no groundwater or parafluvial inflows. That $\mathrm{Cl}$ concentrations do not increase over this stretch of river (Fig. 4b) are consistent with it being losing. A $k$ value of 0.3 day $^{-1}$ is at the lower end of estimates of Rn gas transfer coefficients (Genereux and Hemond, 1992; Cook et al., 2003, 2006; Cartwright et al., 2011, 2014; Unland et al., 2013; Yu et al., 2013; Atkinson et al., 2015). However, as the Avon River is dominated by slow-flowing pools, degassing rates are expected to be low.

Groundwater inflows were calculated from the ${ }^{222} \mathrm{Rn}$ activities by solving Eq. (2) using a finite difference approach in a spreadsheet with a distance step of $10 \mathrm{~m}$ (the use of smaller or larger distance steps does not significantly change the results). The streamflow at the Channel gauge was used 


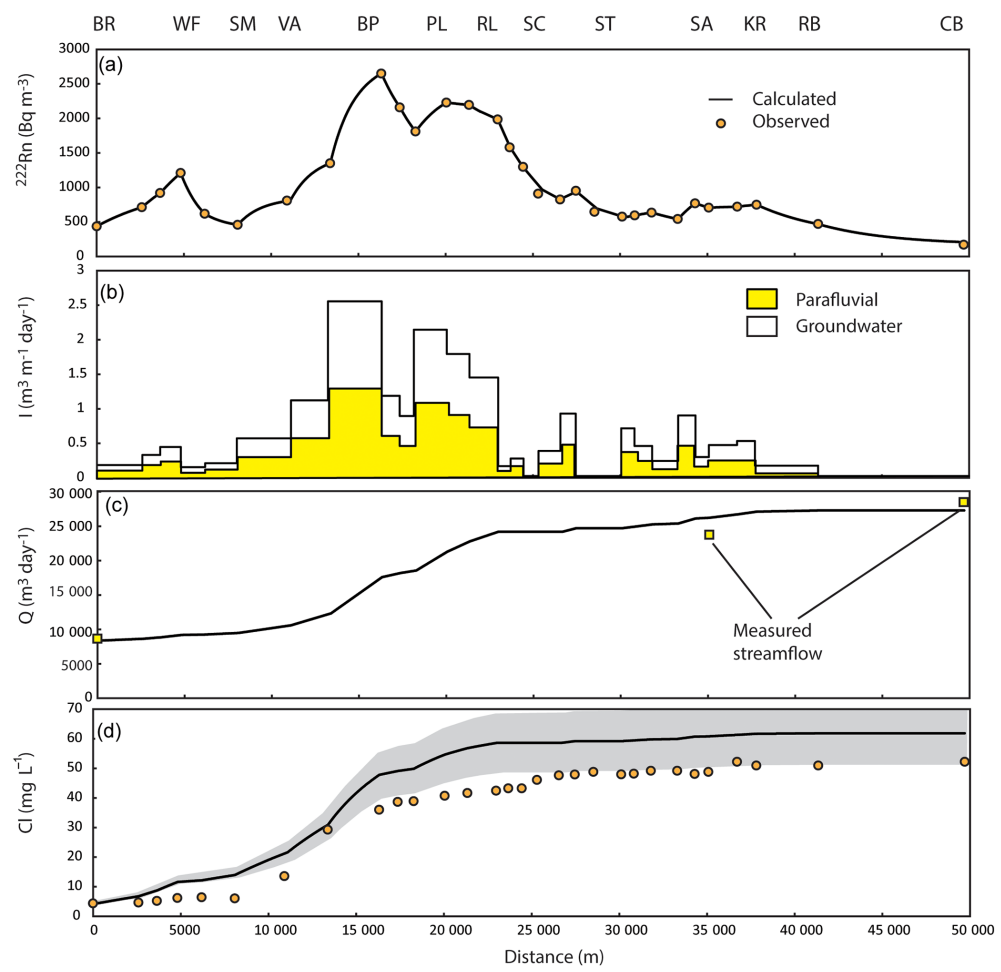

Figure 6. (a) Calculated and observed ${ }^{222} \mathrm{Rn}$ activities for February 2015 resulting from assigning $50 \%$ of the calculated inflows as parafluvial flow. (b) Variation in groundwater and parafluvial inflows. (c) Calculated streamflow resulting from the groundwater inflows (Eq. 2) vs. measured streamflow at Stratford and Chinns Bridge. (d) Predicted vs. observed Cl concentrations. Shaded field is the range resulting from varying groundwater $\mathrm{Cl}$ concentrations within the $95 \%$ confidence interval.

as the initial streamflow and $Q$ was increased after each distance step via Eq. (3). The calculations estimated the values of $I$ and $I_{\mathrm{p}}$ in each reach by matching the calculated and measured ${ }^{222} \mathrm{Rn}$ activities along the river with the additional constraint that the total groundwater inflows cannot exceed the net increase in streamflow between the Channel gauge and the gauges at Stratford and Chinns Bridge (Fig. 1). Since there are few streamflow measurements, the calculations assumed that the ratio of $I$ to $I_{\mathrm{p}}$ was the same in all gaining reaches of the river.

Assuming that in the gaining reaches there are $50 \%$ parafluvial inflows and $50 \%$ groundwater inflows allows both the ${ }^{222} \mathrm{Rn}$ variations and the increase in streamflow to be accounted for (Fig. 6a). Calculated groundwater and parafluvial inflows are highest in the reaches between Smyths Road and Pearces Lane (8.1-20.0 km) (Fig. 6b), which is the region where $\mathrm{Cl}$ concentrations also increase markedly (Fig. 4b). Assuming that the waters are in secular equilibrium with the sediments, the combined inflows of groundwater and parafluvial water for this reach are up $2.5 \mathrm{~m}^{3} \mathrm{~m}^{-1}$ day $^{-1}$ of which groundwater inflows are $\sim 1.26 \mathrm{~m}^{3} \mathrm{~m}^{-1}$ day $^{-1}$.

There is no process in the parafluvial or hyporheic zones other than mixing with groundwater that increases the $\mathrm{Cl}$ concentrations of the through-flowing water. Thus, the $\mathrm{Cl}$ concentrations in the river reflect only the groundwater in- flows and in theory it would be possible to use $\mathrm{Cl}$ to quantify these (c.f., McCallum et al., 2012). However, the high variability of $\mathrm{Cl}$ concentrations in the groundwater and the relatively small difference between groundwater and river $\mathrm{Cl}$ concentrations results in large uncertainties. The change in $\mathrm{Cl}$ concentrations (Fig. 6d) was calculated from the groundwater inflows assuming that groundwater has a $\mathrm{Cl}$ concentration of $85 \mathrm{mgL}^{-1}$. The calculated $\mathrm{Cl}$ concentrations are slightly higher than those observed, but if the $\mathrm{Cl}$ concentration of the groundwater is allowed to vary within the $95 \%$ confidence interval $\left( \pm 16 \mathrm{mg} \mathrm{L}^{-1}\right)$ the observed trend can be reproduced.

If residence times in the parafluvial zone are shorter than those required to attain secular equilibrium, $c_{\mathrm{p}}$ will be lower and the inflows from the parafluvial zone $\left(I_{\mathrm{p}}\right)$ required to produce a given flux of ${ }^{222} \mathrm{Rn}\left(F_{\mathrm{p}}\right)$ increases (Fig. 3). For example, if $c_{\mathrm{r}}=2300 \mathrm{Bqm}^{-3}$, which is a typical value in many of the reaches between Valencia and Bushy Park $(10.9-16.3 \mathrm{~km})$ and $c_{\mathrm{p}}=12700 \mathrm{~Bq} \mathrm{~m}^{-3}, \quad$ then $\quad\left(c_{\mathrm{p}}-c_{\mathrm{r}}\right)=10400 \mathrm{Bqm}^{-3}$. If $\quad I_{\mathrm{p}}=1 \mathrm{~m}^{3} \mathrm{~m}^{-1} \mathrm{day}^{-1}, \quad F_{\mathrm{p}}=10400 \mathrm{~Bq} \mathrm{~m}^{-1}$ day $^{-1}$ (Eq. 6). If $\gamma=2300 \mathrm{Bqm}^{-3} \mathrm{day}^{-1}, c_{\mathrm{p}}$ is 2487,4023 , and $11004 \mathrm{~Bq} \mathrm{~m}^{-3}$ where $t_{\mathrm{p}}$ is $0.1,1$, and 10 days, respectively. To produce a value of $F_{\mathrm{p}}$ of $10400 \mathrm{~Bq} \mathrm{~m}^{-1}$ day $^{-1}$ requires $I_{\mathrm{p}} \sim 58 \mathrm{~m}^{3} \mathrm{~m}^{-1}$ day $^{-1}$ for $t_{\mathrm{p}}=0.1$ days, $\sim 6.0 \mathrm{~m}^{3} \mathrm{~m}^{-1}$ day $^{-1}$ 


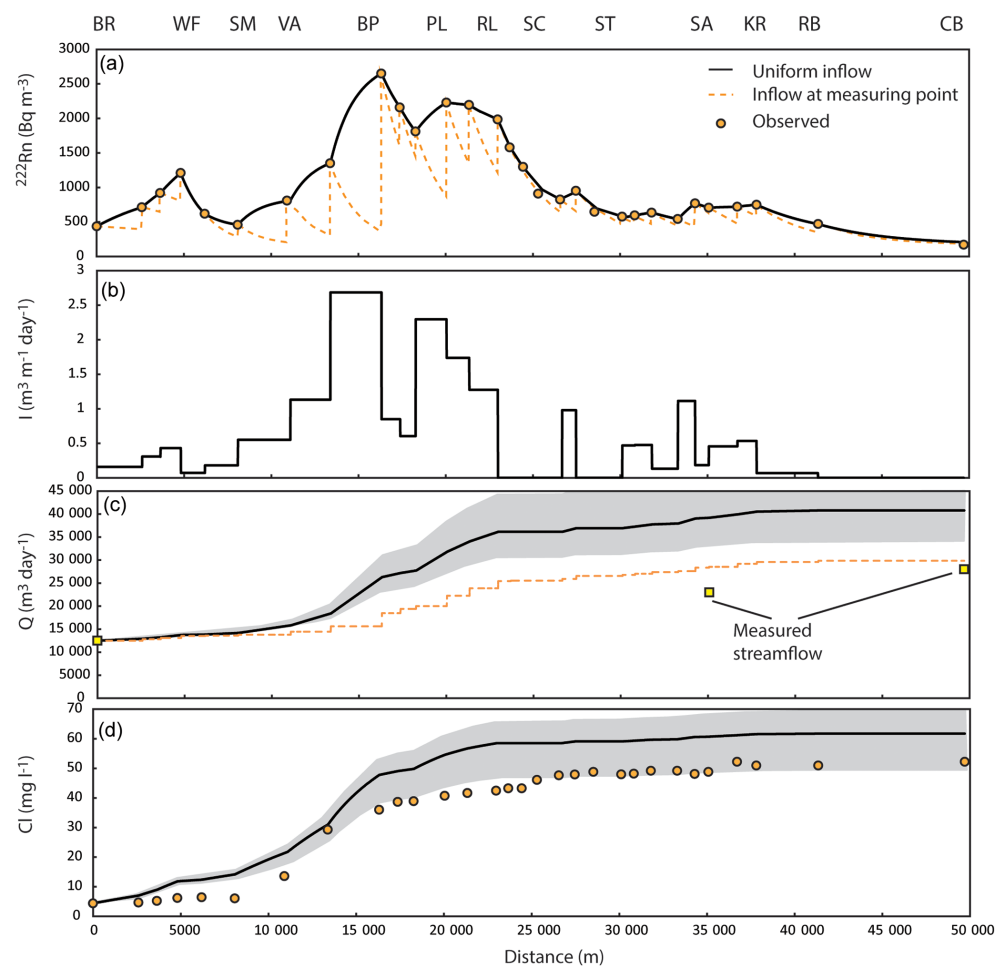

Figure 7. (a) Calculated vs. observed ${ }^{222} \mathrm{Rn}$ activities in the Avon River for February 2015 assuming both uniform groundwater inflow within each reach and the situation where groundwater inflow occurs immediately upstream of the measurement point. Site abbreviations are as for Fig. 2. (b) Calculated groundwater inflows $(I)$ assuming uniform inflows within each reach. (c) Calculated increase in streamflow from groundwater inflows (Eq. 2). Both uniform groundwater inflow within each reach and the situation where groundwater enters the river immediately upstream of the measurement point overestimate the measured streamflow. Shaded area is the range of streamflow resulting from varying $c_{\mathrm{gw}}$ within the $95 \%$ confidence interval. (d) Predicted vs. observed $\mathrm{Cl}$ concentrations. Shaded field is the range resulting from varying groundwater $\mathrm{Cl}$ concentrations within the $95 \%$ confidence interval.

for $t_{\mathrm{p}}=1$ day, and $\sim 1.2 \mathrm{~m}^{3} \mathrm{~m}^{-1}$ day $^{-1}$ for $t_{\mathrm{p}}=10$ days. For $t_{\mathrm{p}}>30$ days the system is close to secular equilibrium and $c_{\mathrm{p}}$ and $I_{\mathrm{p}}$ are near constant (Fig. 3). The cross-sectional area of the parafluvial zone $A_{\mathrm{p}}$ required to accommodate these parafluvial flows with $\varphi=0.4$ and $t_{\mathrm{p}}$ between 0.1 and 100 days is between 14 and $250 \mathrm{~m}^{2}$ (Eq. 7). The floodplain of the Avon River is tens of metres wide with sediment thicknesses of several metres and even the higher estimates of the cross-sectional area are not unreasonable given the volume of gravels on the floodplain.

\subsection{Uncertainties and sensitivity}

The proposal that parafluvial flow is important in the Avon River is consistent with the local hydrogeology and allows both the ${ }^{222} \mathrm{Rn}$ and net increase in streamflow to be reproduced. The conclusion that inflows of parafluvial zone waters only occur in the gaining reaches is justifiable as the conditions required for groundwater inflows (gaining river with steep hydraulic gradients and high-hydraulic conductivity sediments) will likely drive the return of parafluvial waters to the river. By contrast, losing reaches are likely to be where the water enters the parafluvial sediments. Given the multiple parameters in Eq. (2) and their inherent uncertainties, however, consideration needs to be given to whether both the ${ }^{222} \mathrm{Rn}$ activities and the increases in streamflow can be accounted for without parafluvial inflows being a significant source of ${ }^{222} \mathrm{Rn}$.

Matching the ${ }^{222} \mathrm{Rn}$ profile along the Avon River using the parameters discussed above but without input of ${ }^{222} \mathrm{Rn}$ from parafluvial zone would imply net groundwater inflows of $28300 \mathrm{~m}^{3} \mathrm{day}^{-1}$. However, these inflows exceed the measured increase in streamflow between the Channel and Chinns Bridge of $15500 \mathrm{~m}^{3}$ day $^{-1}$ by $180 \%$ (Fig. 7a). The February 2015 sampling round took place at the end of summer when the small ephemeral tributaries were dry and there was no overland flow; however, there were still flows from Valencia Creek and Freestone Creek of 1410 and $200 \mathrm{~m}^{3} \mathrm{day}^{-1}$, respectively. If these were included, the discrepancy between the calculated and observed streamflow increases. The calculated $\mathrm{Cl}$ concentrations are also higher than observed (Fig. 7d), although given the uncertainty in groundwater $\mathrm{Cl}$ concentrations the discrepancy is not large.

In common with most studies, the calculations assumed that the groundwater inflows are uniform along a particu- 


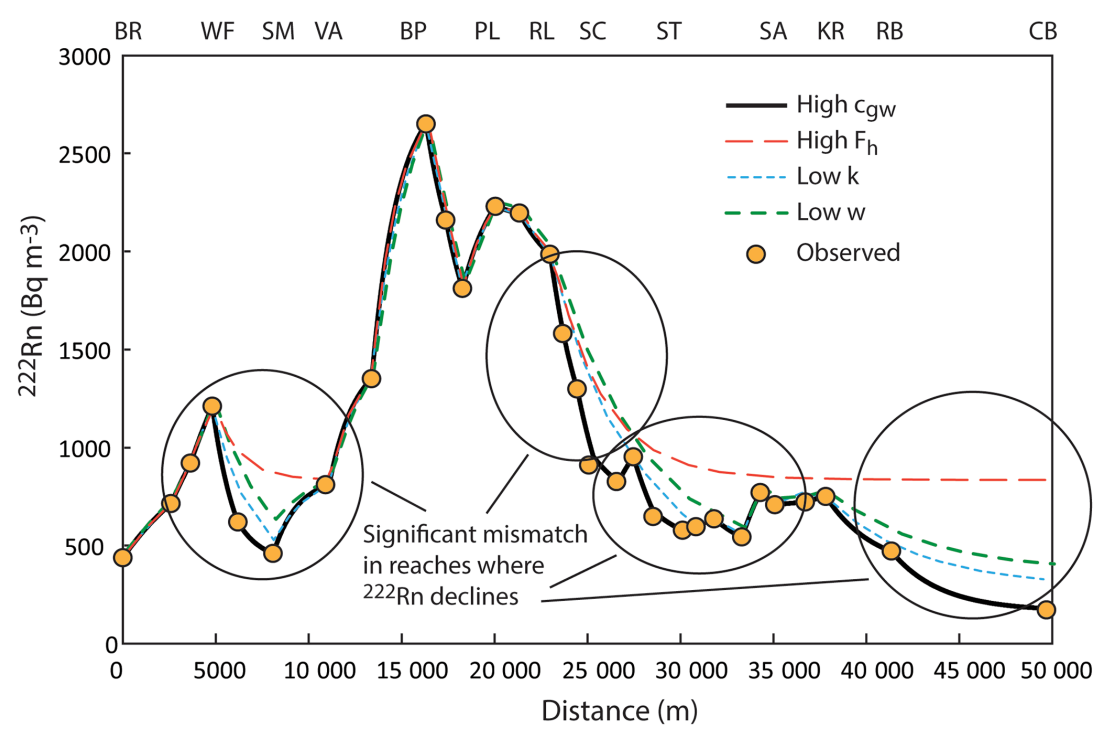

Figure 8. Calculated and observed ${ }^{222} \mathrm{Rn}$ activities for February 2015 resulting from varying individual parameters in Eq. (1). In all cases the new parameters result in significant overestimation of ${ }^{222} \mathrm{Rn}$ activities in many reaches and are unlikely to be realistic. Site abbreviations are as for Fig. 1.

lar reach. However, because ${ }^{222} \mathrm{Rn}$ is lost from rivers by degassing and decay, lower groundwater inflows are required to replicate the observed ${ }^{222} \mathrm{Rn}$ activities if the groundwater inflows occur immediately upstream of a sampling point (Cook, 2013). Even assigning the groundwater inflows in each reach to the $10 \mathrm{~m}$ section upstream of the measurement point still results in the calculated streamflow overestimating the measured streamflow (Fig. 7c). The predicted ${ }^{222} \mathrm{Rn}$ activities in the river in this case are also not realistic (Fig. 7a).

The evaporation term in Eq. (2) is 1-2 orders of magnitude lower than most of the other terms, and errors in the assumed evaporation rate have little influence on the calculations. The main parameter impacting calculated groundwater inflows is the ${ }^{222} \mathrm{Rn}$ activity of groundwater (Cartwright et al., 2011; Cook, 2013). Allowing $c_{\mathrm{gw}}$ to vary within the $95 \%$ confidence interval of the groundwater ${ }^{222} \mathrm{Rn}$ activities $\left( \pm 2600 \mathrm{~Bq} \mathrm{~m}^{-3}\right)$ makes little difference to the discrepancy between the calculated and observed increase in streamflow (Fig. 7c). Increasing $c_{\mathrm{gw}}$ to $27000 \mathrm{~Bq} \mathrm{~m}^{-3}$ allows both the ${ }^{222} \mathrm{Rn}$ profile and the observed increase in streamflow between the Channel and Chinns Bridge to be reproduced without the requirement for the input of ${ }^{222} \mathrm{Rn}$ from the parafluvial zone (Fig. 8). However, there is no known groundwater in the Avon catchment with such high ${ }^{222} \mathrm{Rn}$ activities and these activities are far higher than would be in equilibrium with the alluvial sediments that comprise the near-river aquifer lithologies. Hence, it is considered not possible that groundwater ${ }^{222} \mathrm{Rn}$ activities could be this high.

There is uncertainty in the gas transfer coefficient. $k$ was estimated assuming that the Avon River contains losing reaches; if those reaches were actually gaining then this methodology underestimates $k$. However, increasing $k$ from 0.3 day $^{-1}$ increases the calculated groundwater inflows, which increases the discrepancy between the observed and calculated increases in streamflow. $k$ estimated from Eqs. (8) and (9) ranges between 0.1 and 0.3 day $^{-1}$. Using $k=0.1$ day $^{-1}$ produces net groundwater inflows that more closely match the observed increase in streamflow. However, adopting $k=0.1$ day ${ }^{1}$ results in the calculated ${ }^{222} \mathrm{Rn}$ activities in a number of reaches being overestimated (Fig. 8). This is because even assuming no groundwater inflows into those reaches, the loss of ${ }^{222} \mathrm{Rn}$ by degassing is insufficient to explain the observed decrease in ${ }^{222} \mathrm{Rn}$. Such a poor correspondence between predicted and observed ${ }^{222} \mathrm{Rn}$ activities implies problems with the adopted variables.

While there are uncertainties in $c_{\mathrm{h}}$, the main uncertainty in the contribution of hyporheic exchange to the ${ }^{222} \mathrm{Rn}$ budget is the dimensions of the hyporheic zone. Increasing $F_{\mathrm{h}}$ also reduces the calculated groundwater inflows. Using the same emanation rates, residence times, and porosities but assigning a thickness of the hyporheic zone of $50 \mathrm{~cm}$ increases $F_{\mathrm{h}}$ and produces groundwater inflows that broadly match the increase in streamflow. However, the higher values of $F_{\mathrm{h}}$ again result in a poor fit between predicted and observed ${ }^{222} \mathrm{Rn}$ activities (Fig. 8).

Because the error in $\lambda$ is negligible and the evaporation term is much smaller than the other terms, it is generally possible to produce identical trends in ${ }^{222} \mathrm{Rn}$ activities with different combinations of $k$ and $F_{\mathrm{h}}$ (Cartwright et al., 2014). If $F_{\mathrm{h}}$ is calculated assuming a $50 \mathrm{~cm}$ thick hyporheic zone, adopting $k=0.6$ day $^{-1}$ reproduces the observed ${ }^{222} \mathrm{Rn}$ activities. Similarly, if $k=0.1 \mathrm{day}^{-1}$ a match between the ob- 


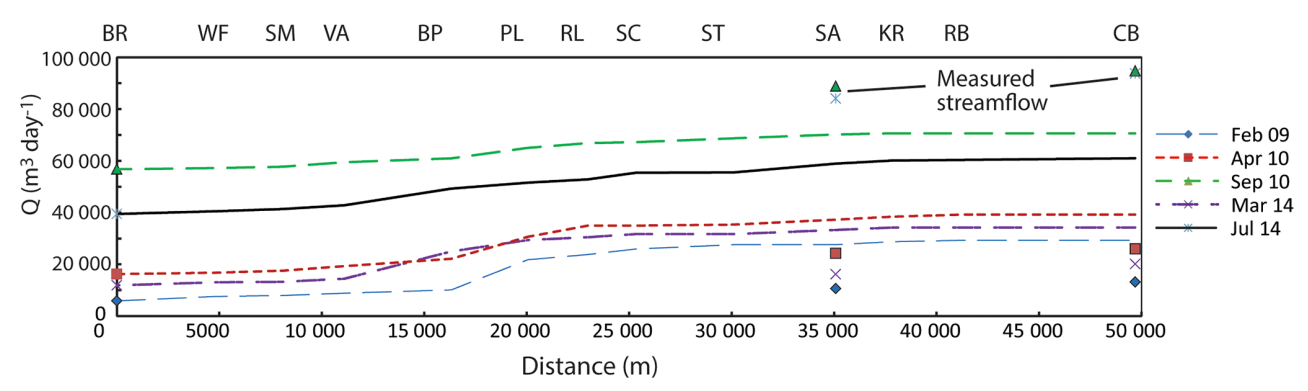

Figure 9. Calculated streamflows resulting from groundwater inflows for the sampling rounds excluding February 2015 estimated without parafluvial flow. Aside from the high flow periods (September 2010 and July 2014) the calculated increase in streamflow exceeds the observed streamflow at Stratford and Chinns Bridge. Site abbreviations are as for Fig. 1.

served and the predicted ${ }^{222} \mathrm{Rn}$ activities is achieved with no hyporheic exchange $\left(F_{\mathrm{h}}=0\right)$. However, these combinations of parameters again result in estimated net groundwater inflows that exceed the measured increase in streamflow.

There is an unknown error in the streamflow measurements, but it is unlikely to be sufficient to explain the gross overestimation of groundwater inflows. Uncertainties in the assumed river widths and depths will also impact the calculations. Specifically, reducing the width or depth decreases the magnitude of the last two terms on the right-hand side of Eq. (2), which in turn reduces $I$. If widths were reduced by $50 \%$ (an unrealistic error), net groundwater inflows broadly match the increase in streamflow. However, this again results in ${ }^{222} \mathrm{Rn}$ activities being overestimated in many reaches (Fig. 8). Increasing $k$ to 0.65 day $^{-1}$ would allow the ${ }^{222} \mathrm{Rn}$ activities to be predicted using these lower widths but again results in the estimated net groundwater inflow exceeding the measured increase in streamflow. Overall it is concluded that there are no combinations of parameters that can reproduce both the observed ${ }^{222} \mathrm{Rn}$ activities and streamflows without incorporating parafluvial flow.

It would be possible to explain the observed ${ }^{222} \mathrm{Rn}$ activities and streamflows if there were losing reaches in the Avon River through which significant volumes of river water were lost to the underlying aquifers and, unlike parafluvial flow, this water did not subsequently return to the river. For this scenario to be valid, approximately $50 \%$ of the groundwater inflows would have to be lost from the river in these losing reaches in February 2015. The reaches between 25 are $30 \mathrm{~km}$ are interpreted as losing. However, these reaches do not dry up even during prolonged drought (Gippsland Water, 2012), and all reaches of the river were flowing during the 2009 sampling campaign (which had the lowest streamflows). Also while streamflows were not measured, such a major reduction in streamflow over such a short distance would be apparent in the field. Likewise, significant pumping of water from the river would also reduce streamflows. While the surface water is licensed for use, streamflow during February 2009 and March 2014 was below the minimum levels where that is permitted and the streamflows in April
2010 and February 2015 were such that use would be restricted; hence, large-scale pumping of river water at those times is unlikely.

\subsection{Other sampling campaigns}

The predicted distribution of groundwater inflows in February 2009, April 2010, and March 2014 when streamflows were low to moderate are similar to those in February 2015 (Fig. 4). Due to the lower number of sampling points, it is difficult to calculate groundwater inflows with certainty. The net groundwater inflows calculated using the same parameters as above but ignoring parafluvial flows are between 15900 and $21700 \mathrm{~m}^{3} \mathrm{day}^{-1}$, respectively (Fig. 9), which are up to $490 \%$ of the measured increases in streamflow between the Channel and Chinns Bridge. Again propagating the likely uncertainties in the parameters through Eq. (2) cannot resolve this discrepancy, implying that the inflows of water from the parafluvial zone must be a significant part of the ${ }^{222} \mathrm{Rn}$ budget.

At the higher streamflows there will likely be significant inputs to the river from overland flow or interflow; hence, it is not possible to use the comparison between calculated groundwater inflows and the net increase in streamflow to independently test for the input of ${ }^{222} \mathrm{Rn}$ from the parafluvial zone. For example, without incorporating parafluvial flow, the net groundwater inflows using widths of $15 \mathrm{~m}$ upstream of Wombat Flat and $25 \mathrm{~m}$ elsewhere, depths of 1.25 upstream of Wombat Flat and $1.6 \mathrm{~m}$ elsewhere, $k=0.3$ day $^{-1}$, $F_{\mathrm{h}}$ adjusted for the higher river widths is $32100 \mathrm{~m}^{3}$ day $^{-1}$ (September 2010) and $44600 \mathrm{~m}^{3} \mathrm{day}^{-1}$ (July 2014). These net groundwater inflows are lower than the measured increases in streamflow between the Channel and Stratford or Chinns Bridge (Fig. 9). However, it is likely that significant parafluvial flow occurs at those times and consequently that these values also represent an overestimation of the actual groundwater inflows. 


\section{Conclusions}

The variation in ${ }^{222} \mathrm{Rn}$ activities and $\mathrm{Cl}$ concentrations clearly define the reaches of the Avon River that are gaining. The distribution of ${ }^{222} \mathrm{Rn}$ activities also indicate that the location of groundwater inflows changed after major floods that occurred between 2011 and 2013. This approach can be applied to other rivers where flood events change the geometry of the floodplain sediments and where the groundwater monitoring bore network is insufficient to define groundwaterriver interaction.

The Avon River has coarse-grained unconsolidated gravels along its floodplain and it was concluded that parafluvial flow was a significant process in controlling the ${ }^{222} \mathrm{Rn}$ activities of the river. However, this proposition is difficult to definitively test or explore in more detail. The groundwater and parafluvial inflows have been assumed to occur in similar proportions in each reach, which may not necessarily be the case. Parafluvial flow is likely to be important in rivers with coarse-grained alluvial sediments on their floodplains, especially where there are locally alternating gaining and losing reaches, and must be taken into account in ${ }^{222} \mathrm{Rn}$ mass balance calculations. Unlike hyporheic exchange, which occurs in all stretches, parafluvial inflows are likely to dominantly occur in gaining reaches augmenting the groundwater inflows.

Theoretically, a conservative tracer such as $\mathrm{Cl}$ that is unaffected by parafluvial flow could be used to separate groundwater inflows from parafluvial inflows. However, the relatively high variability of groundwater $\mathrm{Cl}$ concentrations and the relative small difference between groundwater and river $\mathrm{Cl}$ concentrations make this impractical in the Avon catchment. Nevertheless, this may be possible in other river catchments and illustrates the advantage of using multiple geochemical tracers.
More generally, this study illustrates the importance of carrying out geochemical studies at low streamflows where the majority of inflows into the river are likely to be from groundwater. While this might appear redundant in terms of determining the water balance, it does provide for a test of assumptions and parameterization. It would be possible to interpret the changes to ${ }^{222} \mathrm{Rn}$ activities during the periods of higher streamflow as being solely due to groundwater inflows because the net groundwater inflows are lower than the net increases in streamflow (Fig. 9). However, it is likely that there is groundwater and parafluvial inflows at all times, in which case calculated groundwater inflows will be overestimated.

\section{Data availability}

All geochemistry data used in this study are contained in Tables 2, A1, and A2. The data are available from Ian Cartwright (ian.cartwright@monash.edu). Streamflow data are publicly available from the Victorian State Government Department of Environment and Primary Industries (http: //data.water.vic.gov.au/monitoring.htm). 
Appendix A: Geochemical and streamflow data for the Avon catchment

Table A1. Discharge and geochemistry of the Avon River.

\begin{tabular}{|c|c|c|c|c|c|c|c|}
\hline & \multirow[t]{2}{*}{ Location } & \multirow{2}{*}{$\begin{array}{c}Q \\
\left(\mathrm{~m}^{3} \mathrm{day}^{-1}\right)\end{array}$} & \multirow{2}{*}{$\begin{array}{c}\text { Distance* } \\
(\mathrm{m})\end{array}$} & \multirow{2}{*}{$\begin{array}{c}{ }^{222} \mathrm{Rn} \\
\left(\mathrm{Bqm}^{-3}\right)\end{array}$} & \multirow{2}{*}{$\begin{array}{c}\mathrm{EC} \\
\left(\mu \mathrm{Scm}^{-1}\right)\end{array}$} & \multirow{2}{*}{\multicolumn{2}{|c|}{$\begin{array}{l}\mathrm{Cl} \quad \mathrm{Na} \\
\left(\mathrm{mgL}^{-1}\right)\end{array}$}} \\
\hline & & & & & & & \\
\hline \multirow{10}{*}{ 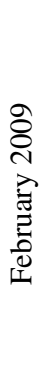 } & Browns & 5890 & 0 & 523 & 89 & 9.4 & 6.8 \\
\hline & Wombat Flat & & 4810 & 2040 & 119 & 10.2 & 7.2 \\
\hline & Valencia & & 10902 & 674 & 265 & 22.6 & 14.6 \\
\hline & Bushy Park & & 16312 & 608 & 352 & 32.1 & 17.8 \\
\hline & Pearces Lane & & 20043 & 3689 & 341 & 35.3 & 19.9 \\
\hline & Schools Lane & & 25304 & 1813 & 527 & 51.3 & 34.5 \\
\hline & Stewarts Lane & & 30112 & 1021 & 551 & 50.8 & 37.1 \\
\hline & Stratford & 10670 & 35076 & 275 & 508 & 55.1 & 41.7 \\
\hline & Redbank & & 41344 & 550 & 711 & 56.8 & 43.8 \\
\hline & Chinns Bridge & 13220 & 49690 & 143 & 590 & 58.0 & 47.2 \\
\hline \multirow{12}{*}{$\begin{array}{l}\frac{0}{0} \\
\frac{1}{1} \\
\frac{0}{2}\end{array}$} & Browns & 16270 & 0 & 400 & 54 & 4.7 & 5.2 \\
\hline & Wombat Flat & & 4810 & 650 & 57 & 5.0 & 5.4 \\
\hline & Smyths Road & & 8080 & 502 & 70 & 7.4 & 6.2 \\
\hline & Valencia & & 10902 & 825 & 109 & 9.2 & 9.1 \\
\hline & Bushy Park & & 16312 & 850 & 167 & 17.5 & 13.8 \\
\hline & Pearces Lane & & 20043 & 2296 & 180 & 18.4 & 14.2 \\
\hline & Ridleys Lane & & 22980 & 2028 & 246 & 23.9 & 19.5 \\
\hline & Schools Lane & & 25304 & 801 & 337 & 35.3 & 24.5 \\
\hline & Stewarts Lane & & 30112 & 508 & 388 & 35.1 & 26.2 \\
\hline & Stratford & 24300 & 35076 & 620 & 485 & 42.0 & 30.5 \\
\hline & Knobs Reserve & & 37813 & 728 & 425 & 44.2 & 31.9 \\
\hline & Chinns Bridge & 26010 & 49690 & 167 & 531 & 47.9 & 35.1 \\
\hline \multirow{13}{*}{ 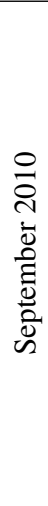 } & Browns & 56750 & 0 & 154 & 55 & 3.8 & 3.9 \\
\hline & Wombat Flat & & 4810 & 212 & 60 & 4.2 & 3.9 \\
\hline & Smyths Road & & 8080 & 227 & 59 & 4.3 & 4.0 \\
\hline & Valencia & & 10902 & 420 & 58 & 4.9 & 4.6 \\
\hline & Bushy Park & & 16312 & 363 & 83 & 6.3 & 6.1 \\
\hline & Pearces Lane & & 20043 & 735 & 81 & 7.5 & 6.4 \\
\hline & Ridleys Lane & & 22980 & 675 & 104 & 8.3 & 7.2 \\
\hline & Schools Lane & & 25304 & 493 & 113 & 9.1 & 8.3 \\
\hline & Stewarts Lane & & 30112 & 406 & 102 & 9.2 & 8.7 \\
\hline & Stratford & 88801 & 35076 & 369 & 109 & 9.7 & 9.3 \\
\hline & Knobs Reserve & & 37813 & 314 & 115 & 10.1 & 9.7 \\
\hline & Redbank & & 41344 & 165 & 130 & 12.0 & 10.1 \\
\hline & Chinns Bridge & 94720 & 49690 & 89 & 227 & 19.2 & 14.9 \\
\hline \multirow{12}{*}{ 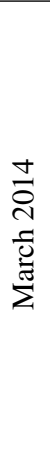 } & Browns & 11920 & 0 & 565 & 131 & 11.3 & 9.2 \\
\hline & Wombat Flat & & 4810 & 1285 & 122 & 10.2 & 7.1 \\
\hline & Smyths Road & & 8080 & 452 & 155 & 13.6 & 9.0 \\
\hline & Valencia & & 10902 & 770 & 243 & 23.4 & 13.2 \\
\hline & Bushy Park & & 16312 & 2735 & 619 & 56.6 & 26.9 \\
\hline & Pearces Lane & & 20043 & 2165 & 608 & 63.7 & 27.0 \\
\hline & Ridleys Lane & & 22980 & 1430 & 598 & 55.2 & 31.6 \\
\hline & Schools Lane & & 25304 & 1245 & 744 & 67.0 & 39.5 \\
\hline & Stewarts Lane & & 30112 & 520 & 772 & 75.3 & 45.9 \\
\hline & Stratford & 16230 & 35076 & 670 & 744 & 76.5 & 47.0 \\
\hline & Knobs Reserve & & 37813 & 710 & 709 & 74.5 & 46.3 \\
\hline & Chinns Bridge & 20120 & 49690 & 74 & 934 & 98.5 & 63.3 \\
\hline
\end{tabular}


Table A1. Continued.

\begin{tabular}{|c|c|c|c|c|c|c|c|}
\hline & \multirow[t]{2}{*}{ Location } & \multirow{2}{*}{$\begin{array}{c}Q \\
\left(\mathrm{~m}^{3} \mathrm{day}^{-1}\right)\end{array}$} & \multirow{2}{*}{$\begin{array}{c}\text { Distance* }^{*} \\
\text { (m) }\end{array}$} & \multirow{2}{*}{$\begin{array}{c}{ }^{222} \mathrm{Rn} \\
\left(\mathrm{Bqm}^{-3}\right)\end{array}$} & \multirow{2}{*}{$\begin{array}{c}\mathrm{EC} \\
\left(\mu \mathrm{Scm}^{-1}\right)\end{array}$} & \multirow{2}{*}{\multicolumn{2}{|c|}{$\begin{array}{l}\mathrm{Cl} \quad \mathrm{Na} \\
\left(\mathrm{mgL}^{-1}\right)\end{array}$}} \\
\hline & & & & & & & \\
\hline \multirow{12}{*}{ 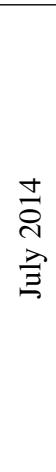 } & Browns & 39470 & 0 & 195 & 78 & 5.8 & 5.3 \\
\hline & Wombat Flat & & 4810 & 370 & 70 & 5.9 & 5.1 \\
\hline & Smyths Road & & 8080 & 338 & 73 & 6.4 & 6.9 \\
\hline & Valencia & & 10902 & 445 & 90 & 7.8 & 8.2 \\
\hline & Bushy Park & & 16312 & 975 & 107 & 8.7 & 9.0 \\
\hline & Pearces Lane & & 20043 & 720 & 180 & 15.3 & 10.5 \\
\hline & Ridleys Lane & & 22980 & 568 & 170 & 17.2 & 12.1 \\
\hline & Schools Lane & & 25304 & 770 & 243 & 20.9 & 14.8 \\
\hline & Stewarts Lane & & 30112 & 302 & 244 & 22.8 & 15.6 \\
\hline & Stratford & 84080 & 35076 & 560 & 262 & 23.8 & 16.5 \\
\hline & Knobs Reserve & & 37813 & 513 & 245 & 25.0 & 17.0 \\
\hline & Chinns Bridge & 93730 & 49690 & 185 & 366 & 36.2 & 23.3 \\
\hline \multirow{30}{*}{ 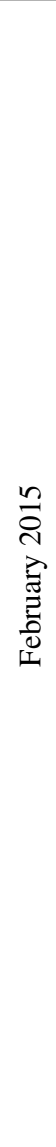 } & Browns & 12510 & 0 & 438 & 56 & 4.4 & 4.8 \\
\hline & BR-WF1 & & 2590 & 714 & 55 & 4.6 & 4.7 \\
\hline & BR-WF2 & & 3638 & 920 & 65 & 5.0 & 4.8 \\
\hline & Wombat Flat & & 4810 & 1210 & 65 & 5.6 & 4.8 \\
\hline & WF-SM & & 6190 & 621 & 70 & 5.8 & 6.1 \\
\hline & Smyths Road & & 8080 & 460 & 76 & 5.5 & 6.1 \\
\hline & Valencia & & 10902 & 810 & 126 & 10.5 & 9.9 \\
\hline & VA-BP & & 13380 & 1350 & 225 & 21.1 & 14.2 \\
\hline & Bushy Park & & 16312 & 2650 & 251 & 25.6 & 15.3 \\
\hline & BP-PL1 & & 17368 & 2160 & 277 & 27.4 & 16.7 \\
\hline & BP-PL2 & & 18723 & 1812 & 298 & 27.5 & 16.9 \\
\hline & Pearces Lane & & 20043 & 2230 & 338 & 28.7 & 17.4 \\
\hline & PL-RL & & 21339 & 2195 & 334 & 29.4 & 17.3 \\
\hline & Ridleys Lane & & 22980 & 1986 & 307 & 29.9 & 18.0 \\
\hline & RL-SC1 & & 23669 & 1580 & 332 & 30.4 & 17.9 \\
\hline & RL-SC2 & & 24439 & 1298 & 315 & 30.4 & 17.7 \\
\hline & Schools Lane & & 25304 & 910 & 352 & 32.3 & 18.0 \\
\hline & SC-ST1 & & 26557 & 827 & 363 & 33.4 & 18.2 \\
\hline & SC-ST2 & & 27462 & 952 & 387 & 33.6 & 18.2 \\
\hline & SC-ST3 & & 28525 & 649 & 385 & 34.1 & 18.7 \\
\hline & Stewarts Lane & & 30112 & 578 & 394 & 33.6 & 18.6 \\
\hline & ST-SA1 & & 30831 & 596 & 323 & 33.7 & 18.8 \\
\hline & ST-SA2 & & 31801 & 637 & 330 & 34.4 & 18.7 \\
\hline & ST-SA3 & & 33301 & 543 & 355 & 34.4 & 18.9 \\
\hline & ST-SA4 & & 34296 & 771 & 366 & 33.7 & 18.7 \\
\hline & Stratford & 23090 & 35076 & 709 & 374 & 34.1 & 19.2 \\
\hline & SA-KR & & 36713 & 722 & 371 & 36.4 & 19.7 \\
\hline & Knobs Reserve & & 37813 & 751 & 390 & 35.6 & 20.1 \\
\hline & Redbank & & 41344 & 471 & 375 & 35.6 & 21.0 \\
\hline & Chinns Bridge & 25780 & 49690 & 172 & 426 & 36.4 & 21.7 \\
\hline
\end{tabular}

* distance downstream from Browns. 
Table A2. Geochemistry of groundwater from Stratford and Pearces Lane.

\begin{tabular}{|c|c|c|c|c|c|c|c|}
\hline \multirow[t]{2}{*}{ Bore } & \multicolumn{3}{|c|}{${ }^{222} \mathrm{Rn}\left(\mathrm{Bqm}^{-3}\right)$} & \multicolumn{2}{|c|}{$\mathrm{EC}\left(\mu \mathrm{Scm}^{-1}\right)$} & \multicolumn{2}{|c|}{$\mathrm{Cl}\left(\mathrm{mgL}^{-1}\right)$} \\
\hline & Apr 2011 & Mar 2012 & Feb 2014 & Apr 2011 & Mar 2012 & Apr 2011 & Mar 2012 \\
\hline Stratford $1^{\mathrm{a}}$ & 3172 & 4332 & 6230 & 207 & 284 & 46 & 59 \\
\hline Stratford 2 & 22896 & 19632 & 28980 & 441 & 361 & 92 & 78 \\
\hline Stratford 3 & 8823 & 9833 & 9540 & 393 & 311 & 85 & 67 \\
\hline Stratford 4 & 11083 & 16073 & 12015 & 490 & 521 & 106 & 119 \\
\hline Pearces $2^{b}$ & 23000 & 21190 & 17560 & 417 & 398 & 89 & 74 \\
\hline Pearces 3 & 9670 & 10320 & 11210 & 294 & 330 & 62 & 71 \\
\hline Pearces 4 & 16800 & 12365 & 14210 & 678 & 575 & 146 & 125 \\
\hline Pearces $5^{c}$ & 480 & 550 & - & 143 & 97 & 31 & 21 \\
\hline
\end{tabular}

a Bores located in bank of river between Stratford and Knobs Reserve sampling sites (Fig. 2).

${ }^{b}$ Bores located in bank of river at Pearces Lane sampling site (Fig. 2).

${ }^{\mathrm{c}}$ Probably sampling parafluvial zone water. 
Author contributions. Both authors were involved in field data collection and lab analyses. Ian Cartwright prepared the manuscript with contributions from Harald Hofmann.

Acknowledgements. We would like to thank Anne Connor, Lee French, Eamon Ley, Massimo Raveggi, and Rachelle Pierson for help in the field and the laboratory. We would also like to thank Luisa Stellato and three anonymous reviewers for their extensive and careful comments on this paper. Funding for this project was provided by Monash University and the National Centre for Groundwater Research and Training program P3. The National Centre for Groundwater Research and Training is an Australian Government initiative supported by the Australian Research Council and the National Water Commission via Special Research Initiative SR0800001.

Edited by: L. Pfister

Reviewed by: L. Stellato and two anonymous referees

\section{References}

Atkinson, A., Cartwright, I., Gilfedder, B., Hofmann, H., Unland, N., Cendón, D., and Chisari, R.: A multi-tracer approach to quantifying groundwater inflows to an upland river; assessing the influence of variable groundwater chemistry, Hydrol. Process., 29, 1-12, 2015.

Barron, O., Silberstein, R., Ali, R., Donohue, R., McFarlane, D. J., Davies, P., Hodgson, G., Smart, N., and Donn, M.: Climate change effects on water-dependent ecosystems in south-western Australia, J. Hydrol., 434-435, 95-109, 2012.

Boulton, A. J., Findlay, S., Marmonier, P., Stanley, E. H., and Maurice Valett, H.: The functional significance of the hyporheic zone in streams and rivers, Annu. Rev. Ecol. Syst., 29, 59-81, 1998.

Bourke, S. A., Cook, P. G., Shanafield, M., Dogramaci, S., and Clark, J. F.: Characterisation of hyporheic exchange in a losing stream using radon-222, J. Hydrol., 519, 94-105, 2014a.

Bourke, S. A., Harrington, G. A., Cook, P. G., Post, V. E., and Dogramaci, S.: Carbon-14 in streams as a tracer of discharging groundwater, J. Hydrol., 519, 117-130, 2014b.

Briody, A. C., Cardenas, M. B., Shuai, P., Knapper, P. S., and Bennett, P. C.: Groundwater flow, nutrient, and stable isotope dynamics in the parafluvial-hyporheic zone of the regulated Lower Colorado River (Texas, USA) over the course of a small flood, Hydrgeol. J., 24, 923-935, doi:10.1007/s10040-016-1365-3, 2016.

Brodie, R., Sundaram, B., Tottenham, R., Hostetler, S., and Ransley, T.: An overview of tools for assessing groundwater-surface water connectivity, Bureau of Rural Sciences, Canberra, Australia, 133 pp., 2007.

Brumley, J.: An investigation of the groundwater resources of the Latrobe Valley, Victoria, in: Symposium on coal resources: origin, exploration and utilization in Australia, edited by: Mallett, C. W., Proceedings, Melbourne, November 1982, Geological Society of Australia, Coal Group, 562-581, 1982.

Bureau of Meteorology: Commonwealth of Australia Bureau of Meteorology, available at: http://www.bom.gov.au, 2015, last accessed 30 June 2015.
Burnett, W. C. and Dulaiova, H.: Radon as a tracer of submarine groundwater discharge into a boat basin in Donnalucata, Sicily, Cont. Shelf Res., 26, 862-873, 2006.

Cartwright, I. and Gilfedder, B.: Mapping and quantifying groundwater inflows to Deep Creek (Maribyrnong catchment, SE Australia) using ${ }^{222} \mathrm{Rn}$, implications for protecting groundwaterdependant ecosystems, Appl. Geochem., 52, 118-129, 2015.

Cartwright, I., Hofmann, H., Sirianos, M. A., Weaver, T. R., and Simmons, C. T.: Geochemical and ${ }^{222}$ Rn constraints on baseflow to the Murray River, Australia, and timescales for the decay of low-salinity groundwater lenses, J. Hydrol., 405, 333-343, 2011.

Cartwright, I., Hofmann, H., Gilfedder, B., and Smyth, B.: Understanding parafluvial exchange and degassing to better quantify groundwater inflows using ${ }^{222} \mathrm{Rn}$ : The King River, southeast Australia, Chem. Geol., 380, 48-60, 2014.

Cecil, L. D. and Green, J. R.: Radon-222, in: Environmental tracers in subsurface hydrology, edited by: Cook, P. G. and Herczeg, A. L., Kluwer, Boston, USA, 175-194, 2000.

Cochrane, G. W., Quick, G. W., and Spencer-Jones, D: Introducing Victorian Geology. Geological Society of Australia, Victorian Division, Melbourne, Australia, 304 pp., 1991.

Cook, P. G.: Estimating groundwater discharge to rivers from river chemistry surveys, Hydrol. Process., 27, 3694-3707, 2013.

Cook, P. G., Favreau, G., Dighton, J. C., and Tickell, S.: Determining natural groundwater influx to a tropical river using radon, chlorofluorocarbons and ionic environmental tracers, J. Hydrol., 277, 74-88, 2003.

Cook, P. G., Lamontagne, S., Berhane, D., and Clarke, J. F.: Quantifying groundwater discharge to Cockburn River, southeastern Australia, using dissolved gas tracers Rn-222 and SF6, Water Resour. Res., 42, W10411, doi:10.1029/2006WR004921, 2006.

Department of Environment and Primary Industries: Streamflow data, available at: http://data.water.vic.gov.au/monitoring.htm (last access: 10 July 2015), 2015.

Edwardson, K. J., Bowden, W. B., Dahm, C., and Morrice, J.: The hydraulic characteristics and geochemistry of hyporheic and parafluvial zones in Arctic tundra streams, north slope, Alaska, Adv. Water Resour., 26, 907-923, 2003.

Ellins, K. K., Roman-Mas, A., and Lee, R.: Using ${ }^{222}$ Rn to examine groundwater/surface discharge interaction in the Rio Grande de Manati, Puerto Rico, J. Hydrol., 115, 319-341, 1990.

Freeze, R. A. and Cherry, J. A.: Groundwater, Prentice-Hall, New Jersey, USA, 604 pp., 1979.

Genereux, D. P. and Hemond, H. F.: Determination of gas exchange rate constants for a small stream on Walker Branch watershed, Tennessee, Water Resour. Res., 28, 2365-2374, 1992.

Gippsland Water: Water Supply Demand Strategy, available at: https://www.gippswater.com.au/application/files/5314/3831/ 1802/Gippsland_Water_Final_2012_WSDS.pdf, last access: 30 May 2015, 2012.

Hester, E. T. and Doyle, M. W.: In-stream geomorphic structures as drivers of hyporheic exchange, Water Resour. Res., 44, W03417, doi:10.1029/2006WR005810, 2008.

Hoehn, E. and Cirpka, O. A.: Assessing residence times of hyporheic ground water in two alluvial flood plains of the Southern Alps using water temperature and tracers, Hydrol. Earth Syst. Sci., 10, 553-563, doi:10.5194/hess-10-553-2006, 2006. 
Hoehn, E. and Von Gunten, H. R.: Radon in groundwater: a tool to assess infiltration from surface waters to aquifers, Water Resour. Res., 25, 1795-1803, 1989.

Hoehn, E., Von Gunten, H. R., Stauffer, F., and Dracos, T.: Radon222 as a groundwater tracer. A laboratory study, Environ. Sci. Technol., 26, 734-738, 1992.

Hofmann, H. and Cartwright, I.: Using hydrogeochemistry to understand inter-aquifer mixing in the on-shore part of the Gippsland Basin, southeast Australia, Appl. Geochem., 33, 84-103, 2013.

Holmes, R. M., Fisher, S. G., and Grimm, N. B.: Parafluvial nitrogen dynamics in a desert stream ecosystem, J. N. Am. Benthol. Soc., 13, 468-478, 1994.

Kløve, B., Ala-aho, P., Bertrand, G., Boukalova, Z., Ertürk, A., Goldscheider, N., Ilmonen, J., Karakaya, N., Kupfersberger, H., Kvœrner, J., Lundberg, A., Mileusnić, M., Moszczynska, A., Muotka, T., Preda, E., Rossi, P., Siergieiev, D., Šimek, J., Wachniew, P., Angheluta, V., and Widerlund, A.: Groundwater dependent ecosystems. Part I: Hydroecological status and trends, Environ. Sci. Pol., 14, 770-781, 2011.

Lamontagne, S. and Cook, P. G.: Estimation of hyporheic water residence time in situ using ${ }^{222} \mathrm{Rn}$ disequilibrium, Limnol. Oceanogr.-Meth., 5, 407-416, 2007.

McCallum, J. L., Cook, P. G., Berhane, D., Rumpf, C., and McMahon, G. A.: Quantifying groundwater flows to streams using differential flow gaugings and water chemistry, J. Hydrol., 416-417, 118-132, 2012.

Mullinger, N. J., Binley, A. M., Pates, J. M., and Crook, N. P.: Radon in Chalk streams: Spatial and temporal variation of groundwater sources in the Pang and Lambourn catchments, UK, J. Hydrol., 339, 172-182, 2007.

Mullinger, N. J., Pates, J. M., Binley, A. M., and Crook, N. P.: Controls on the spatial and temporal variability of ${ }^{222} \mathrm{Rn}$ in riparian groundwater in a lowland Chalk catchment, J. Hydrol., 376, 5869, 2009.

Négrel, P., Casanova, J., and Aranyossy, J.-F.: Strontium isotope systematics used to decipher the origin of groundwaters sampled from granitoids: the Vienne Case (France), Chem. Geol., 177, 287-308, 2001
Negulescu, M. and Rojanski, V.: Recent research to determine reaeration coefficients, Water Res., 3, 189-202, 1969.

O'Connor, D. J. and Dobbins, W. E.: Mechanisms of reaeration in natural streams, T. Am. Soc. Civ. Eng., 123, 641-684, 1958.

Sophocleous, M.: Interactions between groundwater and surface water: the state of the science, Hydrogeol. J., 10, 52-67, 2002.

Stellato, L., Petrella, E., Terrasi, F., Belloni, P., Belli, M., Sansone, U., and Celico, F.: Some limitations in using ${ }^{222} \mathrm{Rn}$ to assess river-groundwater interactions: the case of Castel di Sangro alluvial plain (central Italy), Hydrogeol. J., 16, 701-712, 2008.

Tonina, D. and Buffington, J. M.: Effects of stream discharge, alluvial depth and bar amplitude on hyporheic flow in pool-riffle channels, Water Resour. Res., 47, W08508, doi:10.1029/2010WR009140, 2011.

Unland, N. P., Cartwright, I., Andersen, M. S., Rau, G. C., Reed, J., Gilfedder, B. S., Atkinson, A. P., and Hofmann, H.: Investigating the spatio-temporal variability in groundwater and surface water interactions: a multi-technique approach, Hydrol. Earth Syst. Sci., 17, 3437-3453, doi:10.5194/hess-17-3437-2013, 2013.

Walker, G. and Mollica, F.: Review of the Groundwater Resources in the Southeast Region, Department of Water Resources Victoria, Melbourne, Australia, Report 54, 68 pp., 1990.

Winter, T. C.: Relation of streams, lakes, and wetlands to groundwater flow systems, Hydrogeol. J., 7, 28-45, 1999.

Yu, M. C. L., Cartwright, I., Braden, J. L., and de Bree, S. T.: Examining the spatial and temporal variation of groundwater inflows to a valley-to-floodplain river using ${ }^{222} \mathrm{Rn}$, geochemistry and river discharge: the Ovens River, southeast Australia, Hydrol. Earth Syst. Sci., 17, 4907-4924, doi:10.5194/hess-17-49072013, 2013.

Zarnetske, J. P., Haggerty, R., Wondzell, S. M., and Baker, M. A.: Dynamics of nitrate production and removal as a function of residence time in the hyporheic zone, J. Geophys. Res., 116, G01025, doi:10.1029/2010JG001356, 2011. 